\title{
Michelangelo. Muerte y Resurrección: DE LAS IMÁGENES EN EL SEPULCRO DE GiUliano DE MÉdici
}

\author{
Jesús María GonzÁlez de ZÁrate
}

Universidad del País Vasco

Recibido: 22/09/2015 / Evaluado: 08/03/2016 / Aprobado: 14/04/2016

Resumen: El comentario sobre las tumbas de los Médici en San Lorenzo de Florencia, nos lleva al análisis de su iconografía y, consiguientemente, al estudio de su sentido final en relación con la idea de la Muerte. Escasa iconografía pero suficiente para mostrar la capacidad de todo un genio como lo fue Michelangelo que supo traducir en formas aquella «teología poética» de la que nos hablara Ficino.

Palabras clave: Michelangelo, iconografía, alegoría, muerte, tumbas mediceas.

Abstract: The analysis of the Medicean tombs in San Lorenzo Church in Florence leads us to the analysis of its iconography and, consequently, to the comprehension of its final meaning in relation to the idea of Death. The iconography is not very extense but enough to show Michelangelo's genius who was able to turn into stone Ficino's «poetic theology».

Keywords: Michelangelo, iconography, alegory, death, Medicean tombs. 
$\mathrm{T}_{\mathrm{t}}^{\mathrm{r}}$ ratando de considerar el sentido de la belleza y el amor en Michelangelo, forzosamente hemos de detenernos en los diálogos de Platón como el Fedro y el Banquete. De igual manera, a la hora de comentar la interpretación plástica de la muerte en la escultura del genial florentino, no podemos obviar el Fedón y la literatura neoplatónica que, para esta fecha, revivía con intensidad en la ciudad del Arno con Ficino y la traducción del llamado Corpus Hermeticum.

Fue sin duda el llamado Corpus Hermeticum, considerado escrito por Hermes Trismegisto, uno de los textos sobre la creación que más influyeron entre los platónicos de los siglos XV y XVI florentinos y que, como sabemos, Cosme el Viejo mandara traducir a Ficino del texto griego en el año 1464. El llamado Corpus Hermeticum se pensaba dictado en Egipto ya en los tiempos de Moisés, hoy en día se sabe que responde al pensamiento neoplatónico de comienzos de la Edad Media. Hermes, considerado el inventor de la escritura en Egipto, nos dice que adquirió su conocimiento a través de una visión mística donde contempló el movimiento de las esferas celestes, siendo «Poimandres», la Inteligencia Universal, quien le reveló todos estos misterios cósmicos.

También debemos considerar como fuente singular para intelectuales y artistas los llamados Hieroglyphica, una escritura considerada como ideogramas que tantas respuestas ofreció en las artes del humanismo como lenguaje visual poético y semántico. Su origen lo encontramos en el clérigo y geógrafo florentino Cristóforo Buondelmonti que localizó un pequeño manuscrito en griego de los Hieroglyphica en la isla de Andros hacia 1419 con unas 189 descripciones de figuras y sus interpretaciones. Su valor, hoy en día, es importante pues, aunque escrito en griego, supone el único texto que nos ha llegado que tuvo por objeto la escritura egipcia. El título del manuscrito nos dice: Hoieroglyphica de Horapolo del Nilo que escribió en egipcio y que después Philipo tradujo al griego.

Su llegada a la ciudad del Arno en el año 1421 estableció toda una revolución cultual entre los humanistas y artistas quienes, desde Plinio, sabían de la sabiduría y filosofía contenida en los obeliscos; incluso consideraban que Platón se formó en el país del Nilo. Así, el célebre manuscrito, ignorado en su contenido por Buondelmonti, pasó a las manos de Poggio Bracciolini (traductor de Diodoro Sículo) y a Niccolò de' Niccoli, erudito muy interesado por las cuestiones egipcias. La difusión a partir de la fecha fue singular en el viejo continente y destacaron las ediciones latinas elaboradas en Italia y Francia en los siglos XVI y XVII. En las artes, su huella la apreciamos en composiciones pictóricas y en estampas del siglo xv como daremos cuenta en este comentario.

Los jeroglíficos se consideraban, en consecuencia, un medio, un recurso intelectual para conocer y desvelar aquellos contenidos abstractos del pensamiento y que veremos aplicados en este conjunto escultórico de Michelangelo quien, como advertiremos, no pudo escapar a su influencia. En este sentido se manifiesta el jesuita Kircher en el siglo XVII.

Nos cuenta Tolnay que para este inigualable creador de formas e ideas que nos ha legado el pasado, fueron dos los aspectos que determinaron su obra 
artística, el llamado eros platónico y la inmoralidad del alma, conceptos que, para el historiador, toman su fuente en el pensamiento platónico encarnado por Ficino. ${ }^{1} Y$ es aquí, en su visión de la inmortalidad donde encontraremos toda una filosofía de muerte a través de la singular iconografía que nos presenta. Sin duda, el artista, formado en la filosofía platónica imperante, entendía como se señala en el Fedón que toda la vida es un trabajo preparatorio de la muerte, razón por la que el filósofo no debe temerla, pensamiento muy próximo al que enuncia Séneca siguiendo los principios socráticos en su tratado Sobre la brevedad de la vida (A Paulino, L.V, VII). ${ }^{2}$

La tumba de Julio II en San Pietro in Vincoli (Roma) y la capilla Médici en San Lorenzo (Florencia) serán fiel expresión de este argumento. Vamos a reparar en la segunda y concretamente en la tumba de Giuliano de Médici, duque de Nemours (1479-1516), hijo de Lorenzo el Magnífico y de Clarice Orsini y restaurador del poder de los Médici en Florencia en el año 1512.

El proyecto de este espacio para la muerte, la capilla Médici, fue ideado por Michelangelo a propuesta del papa mediceo Leon X entre los años 15171521. El objetivo buscaba culminar una capilla simétrica a la sacristía vieja que levantara Brunelleschi en el siglo anterior. En su interior, el proyecto del artista ideó una sepultura exenta en el centro de la capilla, más tarde la consideró parietal con dos sepulcros y finalmente adaptó su propuesta a dos sepulturas adosadas como hoy se encuentran [Figs. 1 y 1 bis].
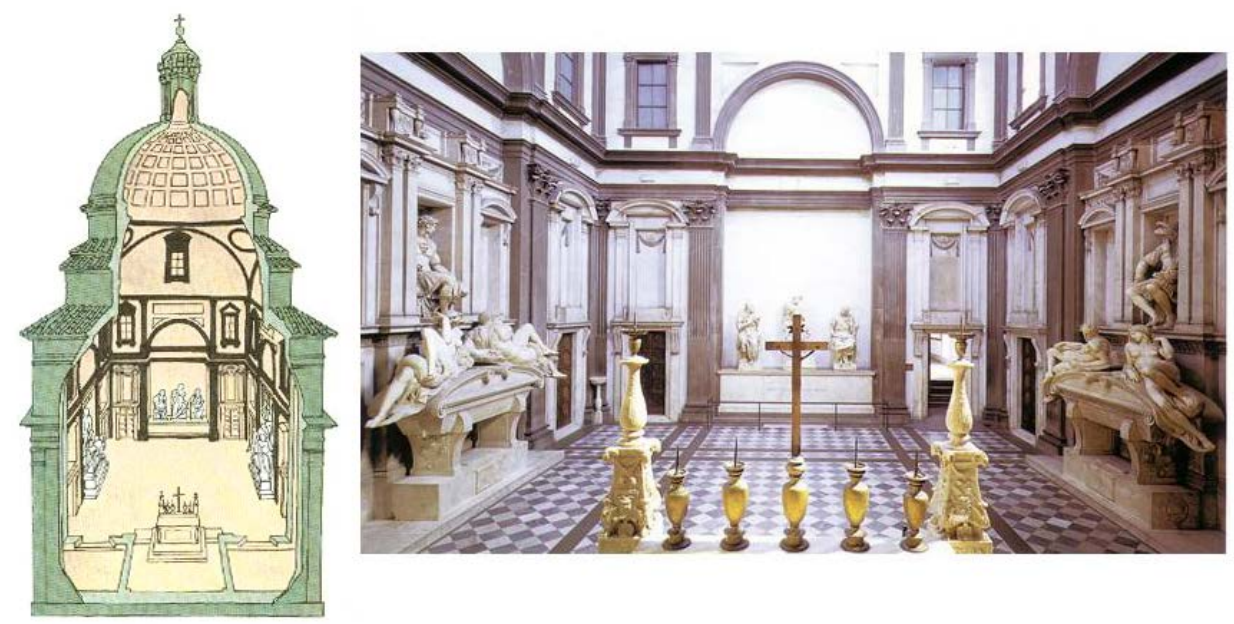

Fig. 1. Michelangelo, Capilla Medicea, sacristía en San Lorenzo, Florencia 1517-1524

1. GonzÁlez de ZÁrate: Mitología e Historia del Arte, T. I., Madrid, 2012.

2. CH. TolnaY: Miguel Ángel escultor, pintor y arquitecto, Madrid, 1985, p. 41.

Precisa Platón en el Fedón: «Los hombres ignoran que los verdaderos filósofos no trabajan durante su vida sino para prepararse a la muerte; y siendo esto así, sería ridículo que después de haber perseguido sin tregua este único fin, recelasen y temiesen, cuando se les presenta la muerte».

Séneca: «Toda la vida se ha de ir estudiando, y lo que más se debe ponderar es que toda ella se ha de gastar en aprender a morir». 

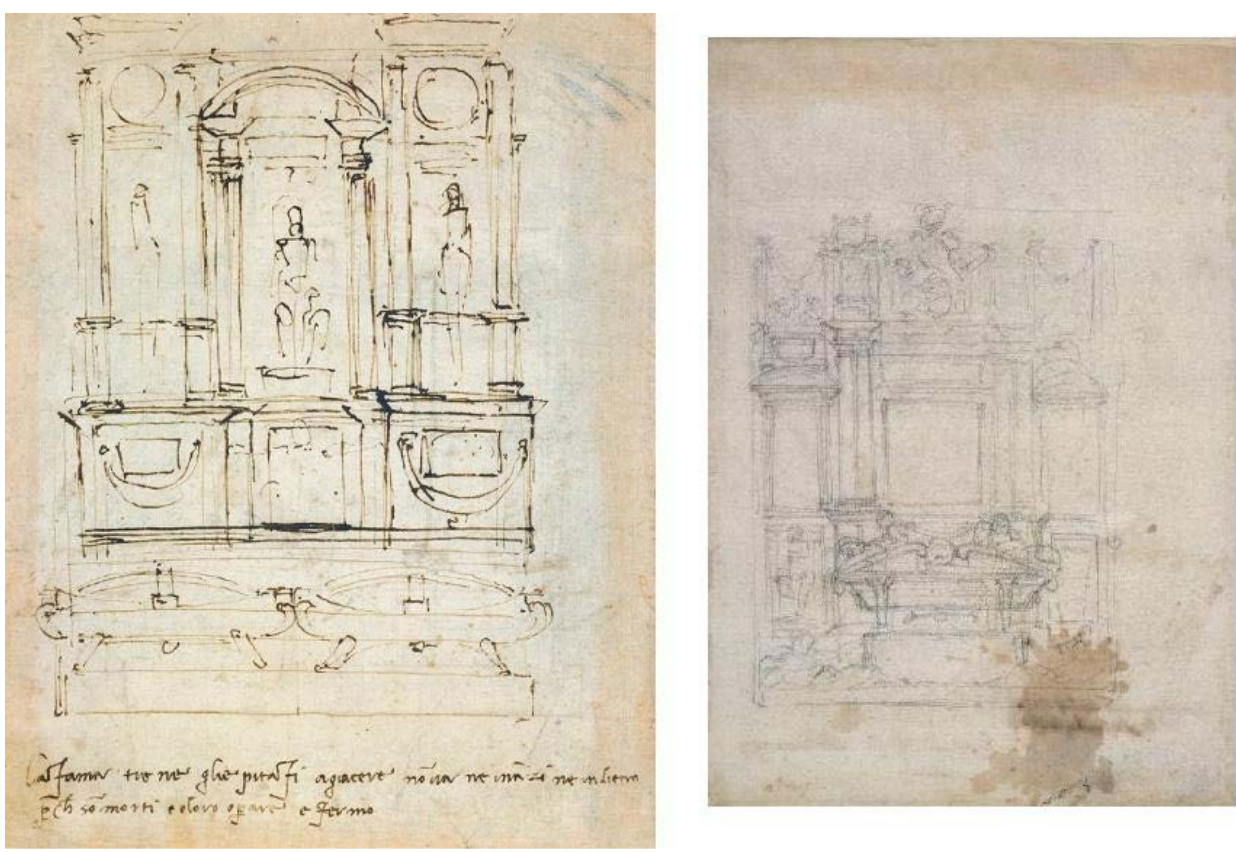

Fig. 1 bis. Dibujos de Michelangelo para las capillas mediceas. Tumba parietal con dos sepulcros y diseño de tumba parietal individualizada, en la zona inferior se pueden observar los ríos del Hades

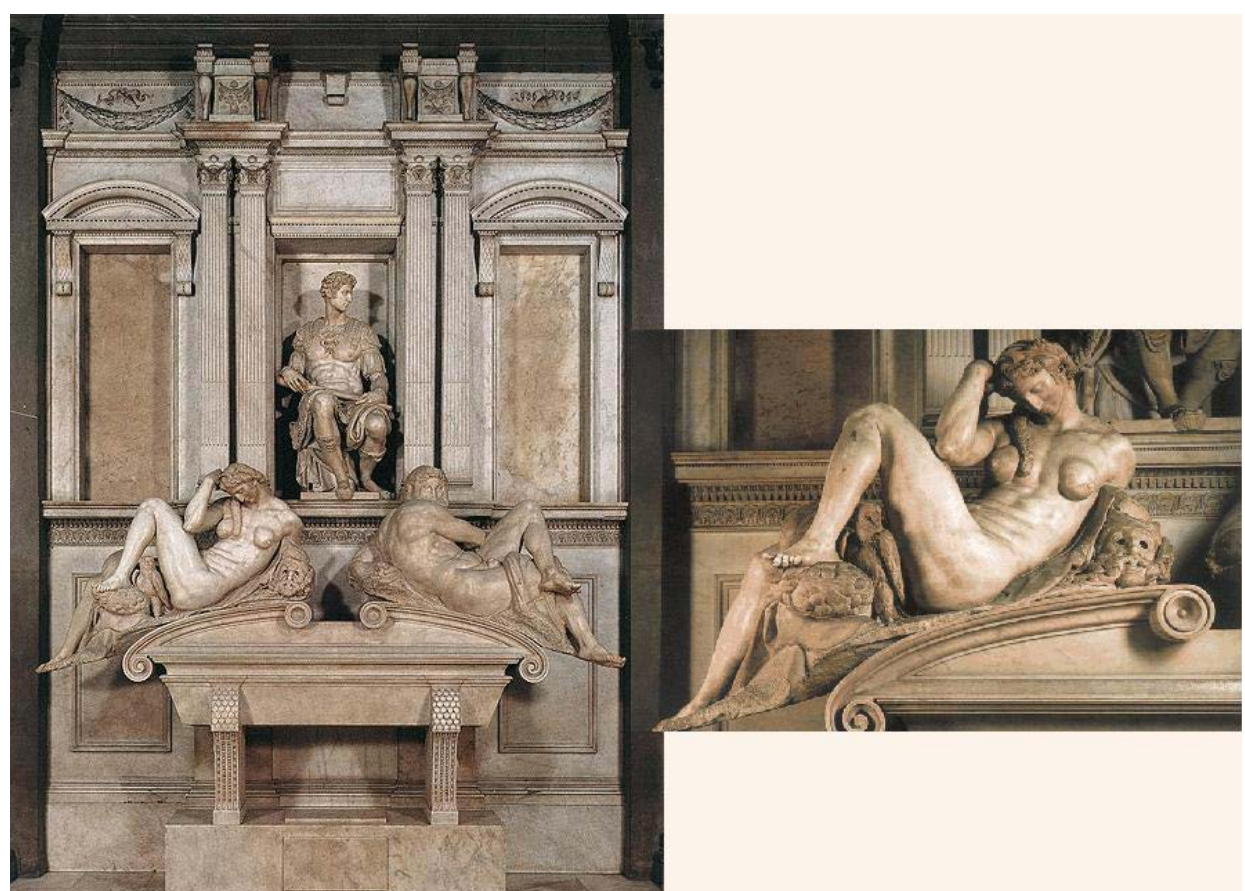

Fig. 2. Michelangelo, Capilla Medicea, tumba de Giuliano de Médici. Alegoría de la Noche 
Tras la extracción del mármol en las canteras toscanas de Carrara entre 1521 y 1524, Michelangelo comenzó su trabajo escultórico. El conjunto combinaba el blanco mármol con la grisacea pietra serena de los muros y se completaría con las decoraciones pictóricas que nunca se llevaron a efecto como recoge Tolnay. ${ }^{3}$

El esquema de la tumba nos remite a lo universal, a una concreta visión del mundo, a la ascensión del alma tras la muerte que, en la tumba de Giuliano, la observamos en diferentes estadios [Fig. 2].

\section{Del Viaje a ultratumba, CASTigo, PURificación y eleVACión}

No solamente las pinturas quedaron en el olvido, el proyecto escultórico tampoco se completó. Así, la zona inferior de las tumbas responderían a un programa concreto fijando en piedra la expresión del Mundo Material, de la materia como centro que atrae toda corporeidad, quedaría figurado iconográficamente por los ríos del Hades como observamos en la recreación [Fig. 3].

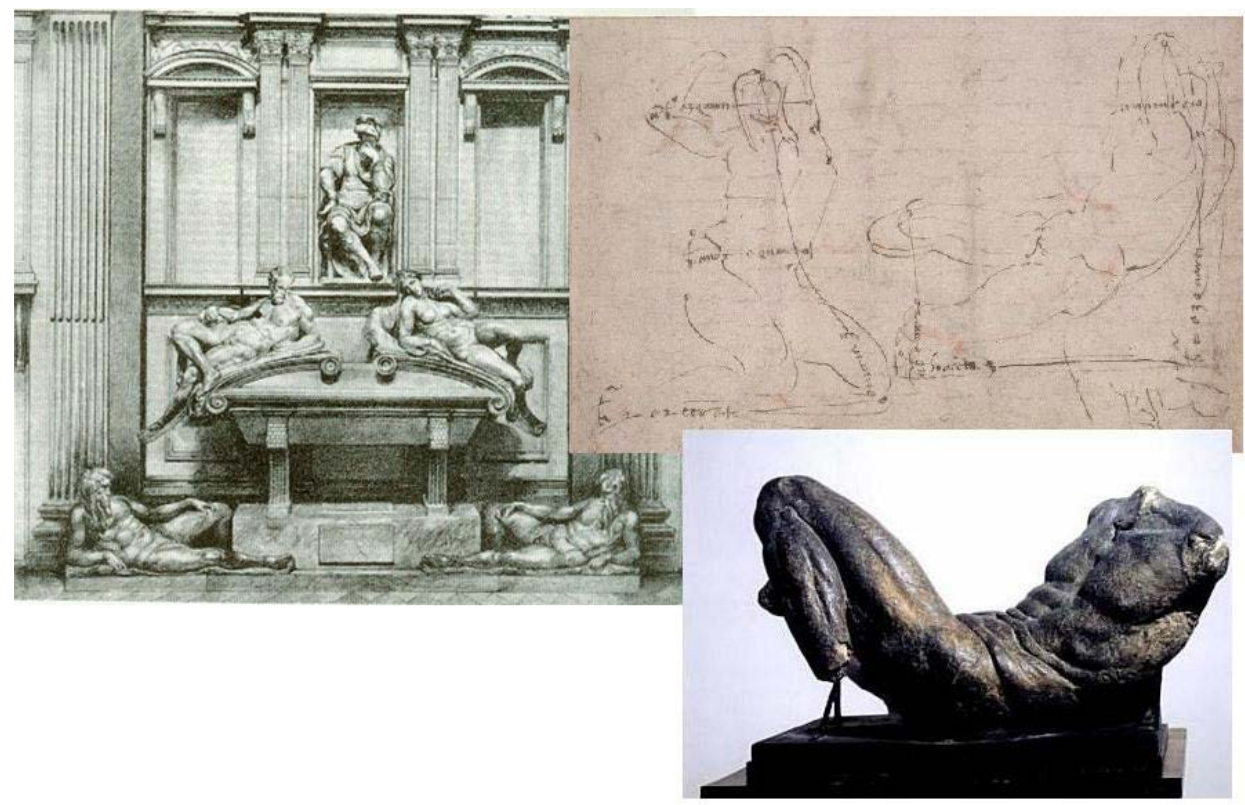

Fig. 3. Michelangelo, Capilla Medicea, recreación con los ríos del Hades en la tumba de Lorenzo, duque de Urbino. Diseño de Michelangelo para los ríos de Hades (1525). Modelo conservado en la casa Buonarroti de Florencia

3. Tolnay, Miguel Ángel escultor, pp. 39-40. Nos dice que en el proyecto se pensaba pintar los lunetos y los muros y que Giovanni da Udine, de la escuela de Rafael, pintó en su tiempo frescos en la cúpula hoy perdidos. 
Es así que Platón considera que el primer camino del alma tras la muerte supone un descenso al reino del Hades rodeado por los ríos infernales (70b):

... las almas, al abandonar este mundo, van al Hades, y desde allí vuelven al mundo y vuelven a la vida, luego de haber pasado por la muerte. Si eso es cierto, y los hombres después de la muerte vuelven a la vida, se sigue de aquí necesariamente que las almas están en el Hades durante este intervalo, porque no volverán al mundo si no existiesen, y será una prueba suficiente de que existen si vemos claramente que los vivos no nacen sino de los muertos...

Una nueva vida tras la muerte, una vida de felicidad que leemos en el Fedón (114b):

Dispuestas así todas las cosas por la naturaleza, cuando los muertos llegan al lugar a que los ha conducido su guía, se los somete a un juicio para saber si su vida en este mundo ha sido santa y justa o no. Los que no han sido ni enteramente criminales ni absolutamente inocentes son enviados al Aqueronte, y desde allí son conducidos en barcas a la laguna Aquerusia, donde habitan sufriendo castigos proporcionados a sus faltas, hasta que, libres de ellos, reciben la recompensa debida a sus buenas acciones. Los que se consideran incurables a causa de lo grande de sus faltas y que han cometido muchos y numerosos sacrilegios, asesinatos inicuos y contra ley u otros crímenes semejantes, el fatal destino, haciendo justicia, los precipita en el Tártaro, de donde no saldrán jamás. Pero los que sólo han cometido faltas que pueden expiarse, aunque sean muy grandes, como haber cometido violencias contra su padre o su madre, $o$ haber quitado la vida a alguno en el furor de la cólera, aunque hayan hecho por ello penitencia durante toda su vida, son sin remedio precipitados también en el Tártaro; pero transcurrido un año, las olas los arrojan y echan a los homicidas al Cocito, y a los parricidas al Piriflegetón, que los arrastra hasta la laguna Aquerusia. Allí dan grandes gritos, y llaman a los que fueron asesinados y a todos aquellos contra quienes cometieron violencias, y los conjuran para que les dejen pasar la laguna, y ruegan se los reciba allí. Si los ofendidos ceden y se compadecen, aquéllos pasan y se ven libres de todos los males; y si no ceden, son de nuevo precipitados en el Tártaro, que los vuelve a arrojar a los otros ríos, hasta que hayan conseguido el perdón de los ofendidos, porque tal ha sido la sentencia dictada por los jueces. Pero los que han justificado haber pasado su vida en la santidad dejan estos lugares terrestres como una prisión y son recibidos en lo alto, en esa tierra pura donde habitan. Y lo mismo sucede con los que han sido purificados por la filosofía, los cuales viven por toda la eternidad sin cuerpo, y son recibidos en estancias aún más admirables.

Es así, que a través de los ríos del Hades se remite al viaje tras la muerte, se manifiesta la idea del Juicio del alma, su castigo, la purificación del espíritu y su ascensión final al paraíso, a la suprema perfección, todo un recorrido expresado en idea que converge claramente con el pensamiento cristiano: 
Y lo mismo sucede con los que han sido purificados por la filosofía, los cuales viven por toda la eternidad sin cuerpo, y son recibidos en estancias aún más admirables.

\section{De LA REgión NATURAL, EL MUNDo MATERIAl SUJETO A LA MUERTE}

Cicerón, en su comentario al Sueño de Escipión, es claro en afirmar que, entre las nueve esferas, todas son eternas salvo la última, la terrena, donde todo está sujeto a la gravedad, a la lo efímero, a la muerte. ${ }^{4}$

Y es así que Michelangelo dispone dos alegorías, el Día y la Noche. El florentino economiza la iconografía y, en pocas imágenes, explica todo el discurso humano en un mundo efímero y temporal donde, siguiendo a Petrarca, se manifiesta todo un triunfo del Tiempo, en su caso, sobre la vida.

La Noche, hija de Caos, expresa el discurrir del tiempo, un destino universal en el medio terreno que se sucede sin remedio para unos y otros sin distinción alguna; pasan días y noches, muchas o pocas, pero el fin es único para todos, una tumba que lleva a la última noche, a la total oscuridad en el hombre. $\mathrm{Y}$ es aquí, con la Noche, donde el florentino hace gala de un conocimiento único no solamente de la forma estética, también de su amplia cultura, de sus conocimientos filosóficos que resume en pocos pero singulares detalles, en una iconografía que, fundamentada en la tradición semántica de la forma, sabe expresarla como nadie.

Entre la vida y el sueño discurre el tiempo, un tiempo asesino que, a modo de Saturno, siega la existencia, vida, sueño y muerte explica el discurso temporal del hombre. La Noche, como señalaba Hesíodo, tuvo dos gemelos, dos, curiosamente el Sueño y la Muerte que, en esta filosofía marmórea se dan cita y acompañan y explican la figura de la Noche.

4. Cicerón: Sobre la República, Gredos, Barcelona, 1995, pp. 158-171.

«Mientras yo proseguía mirando, El Africano siguió hablando: “¿Cuánto tiempo permanecerá tu mente clavada a la Tierra? ¿Contemplas el glorioso Templo al que has llegado? Ahora sabes que el Universo se compone de nueve círculos", o más bien Esferas, todas unidas entre sí, una de las cuales es celestial, y la más lejana, que abarca a todas las demás, la Deidad suprema que conserva y gobierna a las otras. En esta esfera se realizan las revoluciones eternas de las Estrellas, y a ella están sometidas las siete esferas que giran hacia atrás con un movimiento contrario al de la Esfera Celeste. La primera (de las Siete) Esferas está ocupada por la Estrella que en la Tierra se llama Saturno. Luego viene la esfera de esa espléndida Estrella, saludable y afortunada para la raza humana, llamada Júpiter. Luego viene la Esfera Roja, terrible para la Tierra. A la que llamáis Marte. Bajo estas esferas, y casi en la región media, está situado el Sol, el Dirigente. Jefe y Gobernador de las otras Luces. la mente del Mundo y el principio organizador, de tan maravillosa magnitud que ilumina e impregna con su luz todas las partes del Universo. Las Esferas de Venus y Mercurio siguen al Sol en sus respectivos cursos como compañeras suyas. En la Esfera inferior la Luna gira iluminada por los rayos del sol. Bajo ésta en verdad no existe nada que no esté sometido a la muerte y decadencia salvo las Almas, que por donación de los Dioses han sido entregadas a la raza humana. Por encima de la Luna todas las cosas son eternas, pero la Esfera de la Tierra, que ocupa un lugar medio y es la novena, no se mueve: es la más baja y a ella son atraídos todos los cuerpos por su propia gravedad». 


\section{Leemos en la Teogonía:}

Parió la Noche al Maldito Moros, a la Negra Ker y a Thanatos, parió también a Hipnos y engendró la tribu de los Sueños.

Hipnos, sueño y Thanatos, muerte. Ripa, siguiendo a Pausanias nos habla de este asunto, de la Noche, de Hipnos y Thanatos al recordar esculturas antiguas con esta representación:

Mujer vestida con un manto... llevando en la cabeza una corona de adormideras. Con el brazo derecho ha de estar sujetando a un muchachito blanco, y con el izquierdo otro negro y contrahecho de piernas, pareciendo dormidos ambos niños. Casi todo lo expuesto es tal como lo describe Hesíodo.... La corona de adormidera, por sus singulares propiedades que provocan la somnolencia, representa precisamente al Sueño, hijo y efecto de la Noche, el cual se simboliza particularmente mediante el niño que sujeta con la izquierda, que ha de estar durmiendo, mientras que el otro, torcido y contrahecho, representa la Muerte. Así lo explica el escritor griego Pausanias en sus citadas Elíadas, por haberse hallado en sus tiempos una estatua de esta guisa en el interior de un Templo de la Región de la Elide.

Como apreciamos, la Noche pisa con su pie una planta, la adormidera como nos cuenta Tolnay y, por lo mismo, la figuración de Hipnos, el Sueño, pues es su tradicional atributo como apreciamos en esculturas romanas del siglo I como la encontrada en el templo de Afrodita en Cyrene. Andrea Mantegna, fines del siglo xv nos ofrece su dibujo en el que observamos a dos sátiros, uno dispone el almohadón sobre un varón semidesnudo, el otro expande el aire sobre la mujer desnuda; Cupido al igual que los jóvenes, se encuentra sumido en un profundo sueño. Las señaladas alegorías las encontramos en el conocido Sueño del doctor de Alberto Durero. Al fondo de la composición un árbol seco que en su tronco presenta las adormideras como alegoría del sueño que se observa en el espacio amoroso. Robetta, hacia el año 1520 abre su plancha sobre la Alegoría del amor carnal y en ella junto a la pareja amorosa atada por Cupido, presenta en la zona inferior de la estampa otros dos amorcillos que recuerdan los gemelos hijos de la Noche relatados por Pausanias, uno pisando la calavera (Thanatos-muerte) y el otro con dos adormideras en su mano (Hipnos-sueño). Por tanto, el amor como goce pasajero, un mero sueño, que lleva irreductiblemente a la muerte.

Es el tiempo, el paso del día y la noche, el paso de la consciencia al sueño, un asesino que roba la vida. Michelangelo, en su imaginario, lo explica magistralmente. Apreciamos bajo la rodilla de la Noche el búho, ave que pasamos a comentar en el sentido semántico que nos ofrece: la muerte imprevista, el fin del tiempo que nunca tiene anuncio y que provoca la noche final a su capricho [Fig. 4]. 


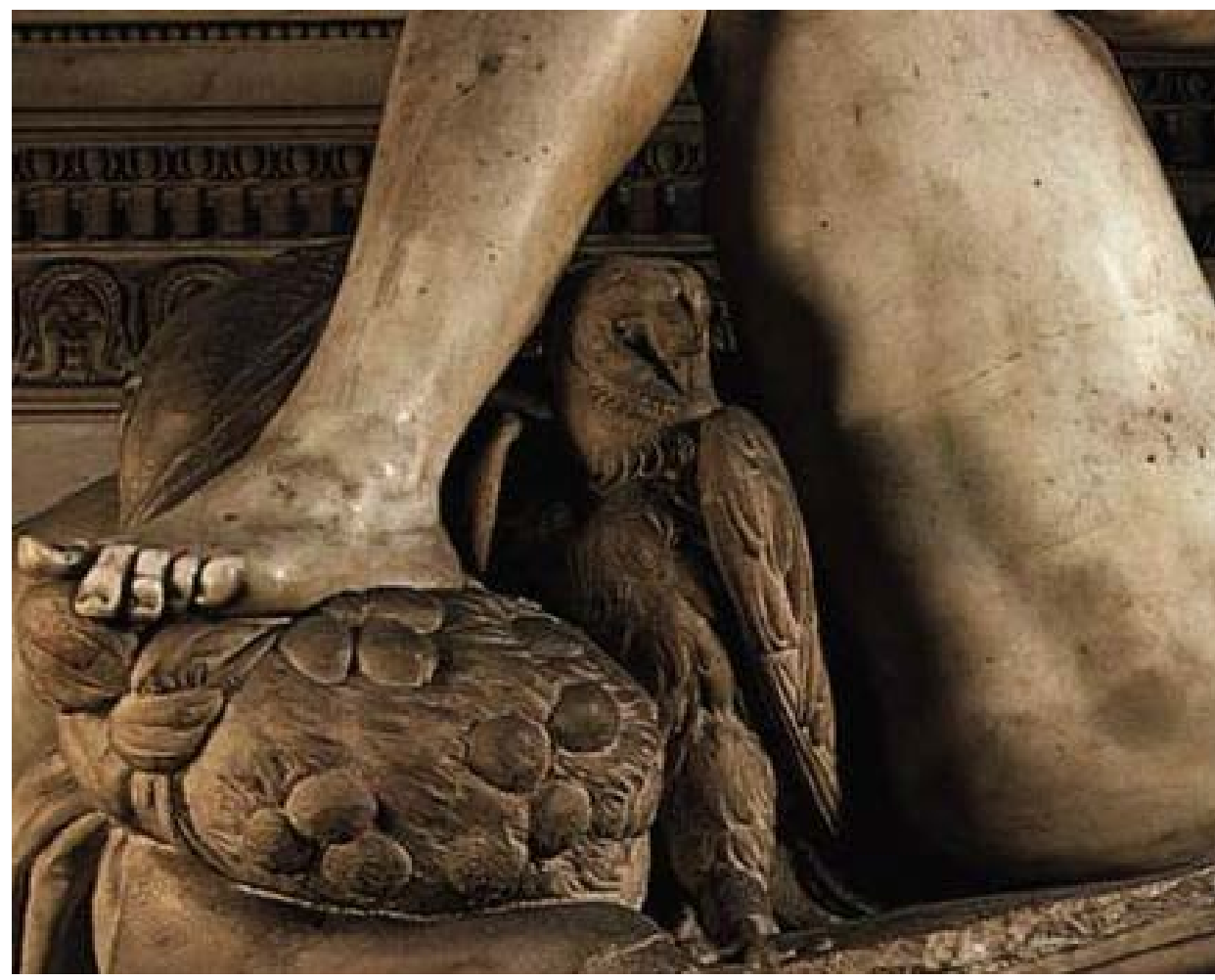

Fig. 4. Michelangelo, Capilla Medicea, El búho y adormidera bajo la figura de la Noche

El genio florentino quiere expresar que la muerte asola en todo tiempo, tanto en la niñez como en la juventud y vejez. Por esta razón se ha de estar preparado para alcanzar la resurrección en Dios, el paso al Hades y la posterior elevación del espíritu como recoge Platón. El tema queda significado por la lechuza o búho, animal propio de Atenea que en los Hieroglyphica no remite a otra cosa, sino a la muerte imprevista [Fig. 5]. Horapolo lo refiere por el llamado cuervo nocturno que en las historias naturales se identifica con el búho, pues como cuervo era conocida el ave en la Antigüedad, para decir:

Un cuervo nocturno representa muerte que se acerca de repente a los polluelos de las cornejas por la noche, como la muerte se acerca de pronto.

La idea toma su fuente de Aristóteles, Plinio, Ovidio y Eliano, se continúa por san Isidoro señalando que es ave propia de cementerios y, en similares términos, la propone Valeriano en su citada Hieroglyphica. ${ }^{5}$

5. GonzÁlez de ZÁrate, J. M.: Los Hieroglyphica de Horapolo, Madrid, 1991, p. 347. Se señalan las fuentes clásicas que hacen corresponder al cuervo nocturno con la lechuza o el búho, es el caso de Aristóteles y Eliano. 


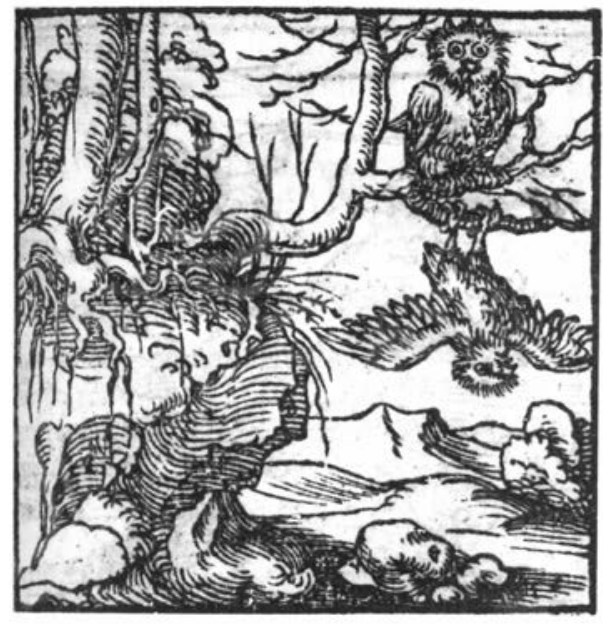

Fig. 5. Horapolo, Hieroglyphica, Muerte imprevista. Cuervo nocturno o búho

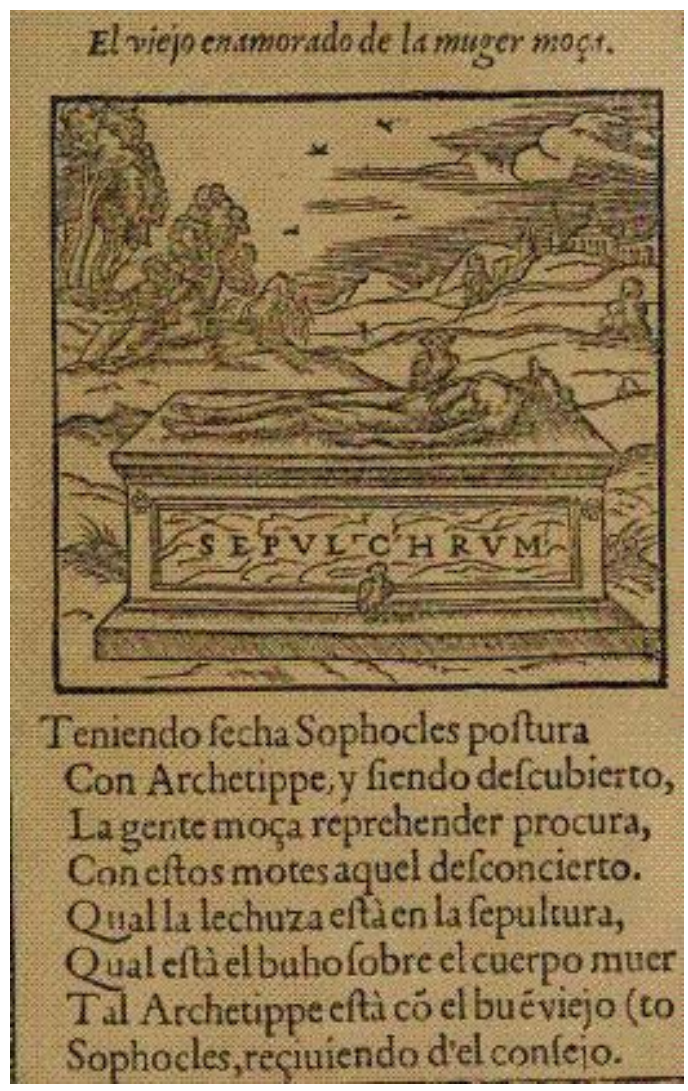

Fig. 6. Alciato, Emblema. El viejo enamorado de la mujer moza 
Los ejemplos del búho con esta significación se suceden en la emblemática como lo apreciamos en los emblemas del holandés Teocritus à Ganda (Heinsius, Daniel) y su Emblemata Amatoria del siglo xvil donde el ave reposa sobre el pecho de un difunto para señalar que la llegada de la muerte es incierta, ${ }^{6}$ así lo observamos en los Emblemas de Alciato [Fig. 6]. ${ }^{7}$ Con el mismo argumento se presenta en el Emblema xxiII de Camerarius, tomando como fuente el citado de Alciato donde el búho reposa sobre un difunto. ${ }^{8}$ Virgilio precisa en la Eneida esta relación del ave con la muerte: «... por los tejados un búho solitario con fúnebre canto» (360-362).

No extraña, por tanto, que el animal resuma en su sentido semántico el propósito de la pintura. La muerte llega de manera imprevista a cualquier edad. Michelangelo lo explica disponiendo el ave como animal nocturno que lleva de manera inexcusable y sin previo aviso a la total oscuridad en el ser humano, es decir, a la muerte como figura y expresión de Thanatos. Así lo apreciamos con anterioridad en la Florencia del siglo xv, concretamente en la estampa de Baccio Baldini donde, la muerte se dispone junto a una pareja que, a modo de vanitas, se recrea con la música. Es la muerte quien toma de su manto a la doncella como imagen de quien a toda edad alcanza de manera imprevista, razón por la que observamos al búho en altura [Fig. 7].

Los ejemplos en la pintura se manifiestan en singulares artistas como Mantegna y su Oración en el huerto de 1489, donde el cuervo reposa sobre un árbol anunciando el prendimiento que llevará a la posterior e inmediata muerte de Cristo [Fig. 8]. En Pieter Brueghel y su Triunfo de la Muerte, pintura elaborada hacia 1562 y que comentaremos más adelante, se nos amonesta sobre la muerte que vence a todo estamento y circunstancia. En la zona izquierda observamos dos pájaros negros, en su caso claramente cuervos, y otro sobre el carro de la muerte arrastrado por el escuálido caballo que porta el cargamento de calaveras. Con anterioridad, Pietro di Giovanni d'Ambrogio hacia 1445 compone su Adoración de los pastores, aquí el búho se dispone en el centro de escena explicando un destino, la muerte no anunciada del Redentor. En el Bosco y su Carro de heno, tabla compuesta hacia 1500, observamos el búho en la rama de un árbol junto a jóvenes de fiesta, el ave anuncia un final inesperado, también en su Ecce Homo de hacia 1475 donde se dispone el ave sobre Pilato como anuncio de una muerte segura e imprevista pues el gobernador romano, siguiendo los apócrifos, prometió a Prócula, su mujer, no condenarlo a muerte. También en el pintor Juan de Flandes y su Natividad de 1508, que ocupa el centro de la composición en referencia a la futura muerte de Cristo desconocida para su madre María. En el artista alemán Hans Baldung Grien

6. HeINSIUS, DANIEL (1580-1655), («Theocritus Ganda»): Emblemata Amatoria. Iam demum emendate, Dirck Pietersz, Amsterdam, 1608. Dispone la lechuza entre las lápidas y el búho sobre el cadáver.

7. Alciato, Andrea: Emblemas, Lyon, 1549, L. II, p. 169. Con el lema: El viejo enamorado de mujer moza.

8. Camerarius, J.: Symbolorum et Emblematum, Edición de Frankfurt, 1654. Centuria ini, Emblema XXIII. 


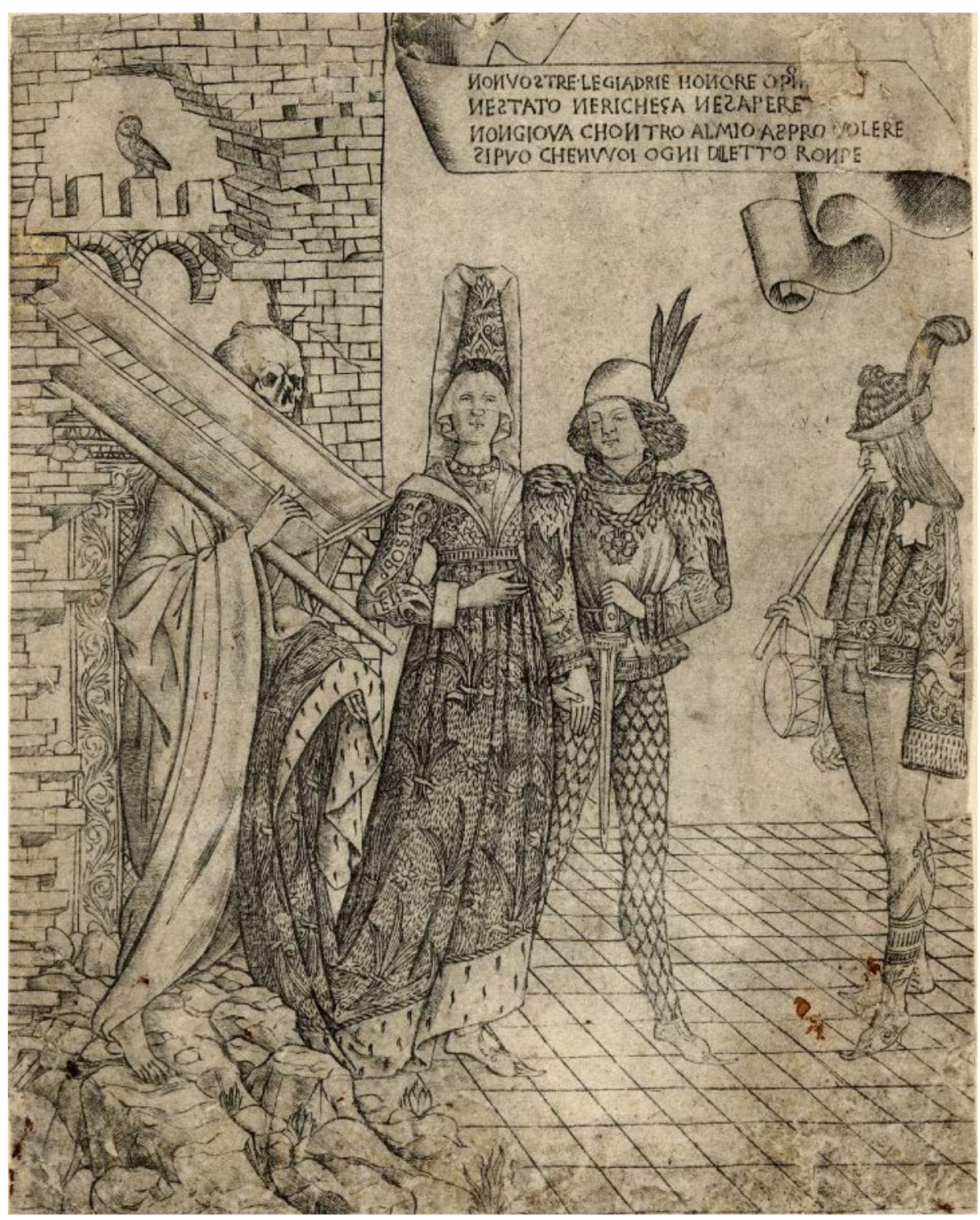

Fig. 7. BaCCio BALDINI, Llegada de la muerte imprevista, 1470

y su argumento sobre las Tres edades y la Muerte elaborado entre los años 1541-1544, que nos presenta a la Muerte acompañada de su reloj de arena y con una lanza rota como anuncio de que la vida se acaba sin aviso alguno a cualquier edad; toma por su brazo a una anciana que arrastra consigo a una joven. En el suelo se dispone un niño, quizá muerto, y el señalado búho que vamos comentando. 


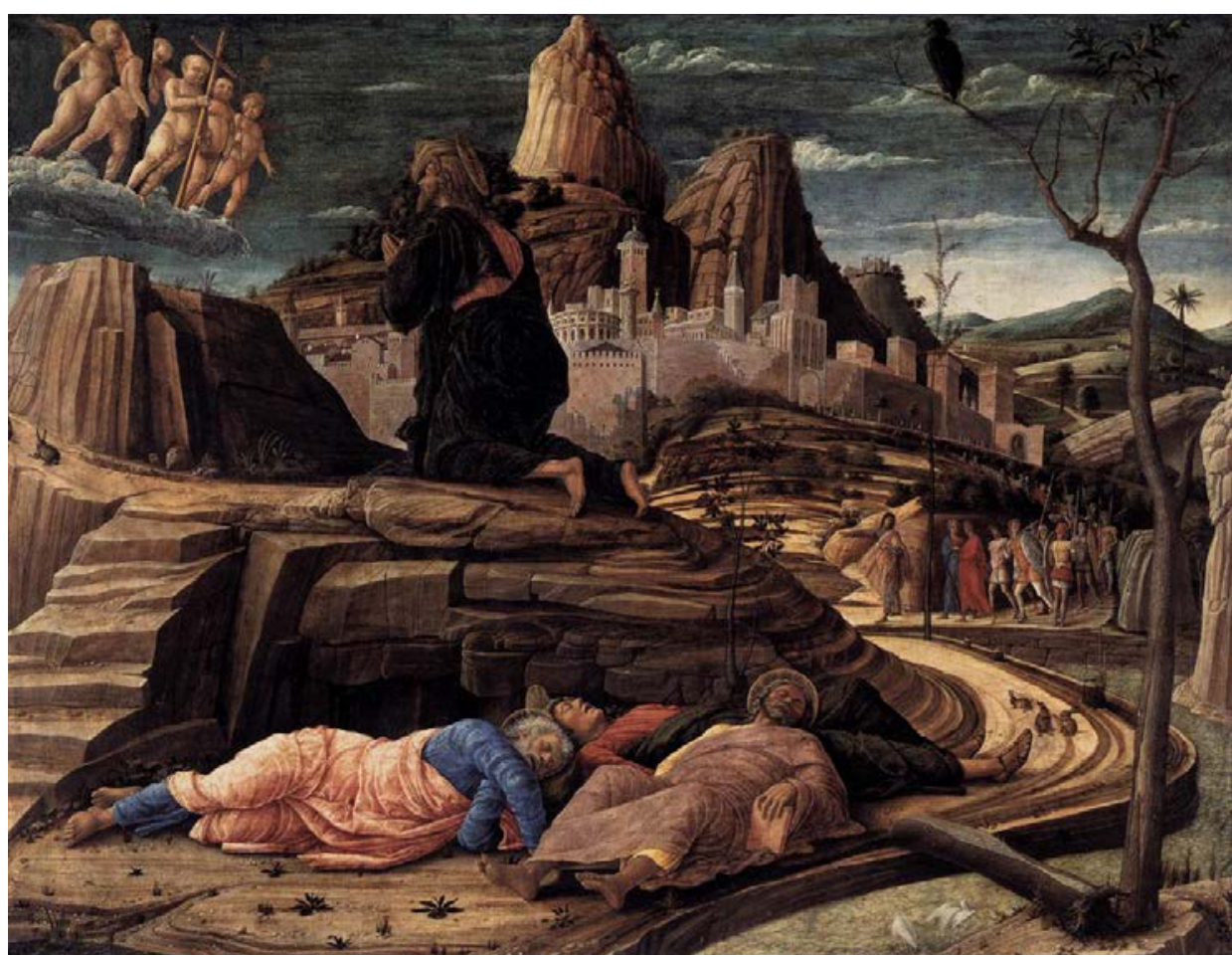

Fig. 8. MANTEGNA, Oración en el huerto, National Gallery, Londres

Es así que, para el pensamiento cristiano, con la caída de los primeros padres llegó la muerte, una muerte que vence a la vida de manera silenciosa. Con esta intencionalidad se recrea al búho en la pintura de Cornelis van Haarlem con este argumento, la Caída de Adán y Eva (1592) que se conserva en el Rijmuseum de Ámsterdam [Fig. 9]. Salvatore Rosa, hacia 1650, presenta al búho en su Demócrito en meditación donde aparece concentrado en la caducidad de la vida y acompañado por los despojos de animales repartidos por el suelo como referencia a lo ef ímero de la vida y la llegada de la muerte sin aviso previo. La estampa del 1500 abierta por el monogramista MZ así lo expresa mediante una mujer que huye de los rayos donde aparece la inscripción DVCK DICH, «escóndete», razón por la que trata de ocultar el búho, expresando con ello el temor a la llegada de una muerte imprevista. ${ }^{9}$

9. Mantegna. Oración en el huerto (National Gallery. Londres). Comentario a la pintura en referencia a los Hieroglyphica en González de ZÁrate, J. M.: Método iconográfico, Vitoria, 1991.

Pieter Brueghel. Triunfo de la Muerte (Museo del Prado).

Giovanni d'Ambrogio. Adoración de los pastores (Museo d'Arte sacra. Asciano).

El Bosco. El carro de heno (Museo del Prado).

El Bosco. Ecce-Homo (Städelsches Kunstinstitut. Fráncfort).

Juan de Flandes. Natividad (Gallery of Art. Washintong).

Hans Baldung Grien. Tres edades y la muerte (Museo del Prado). 


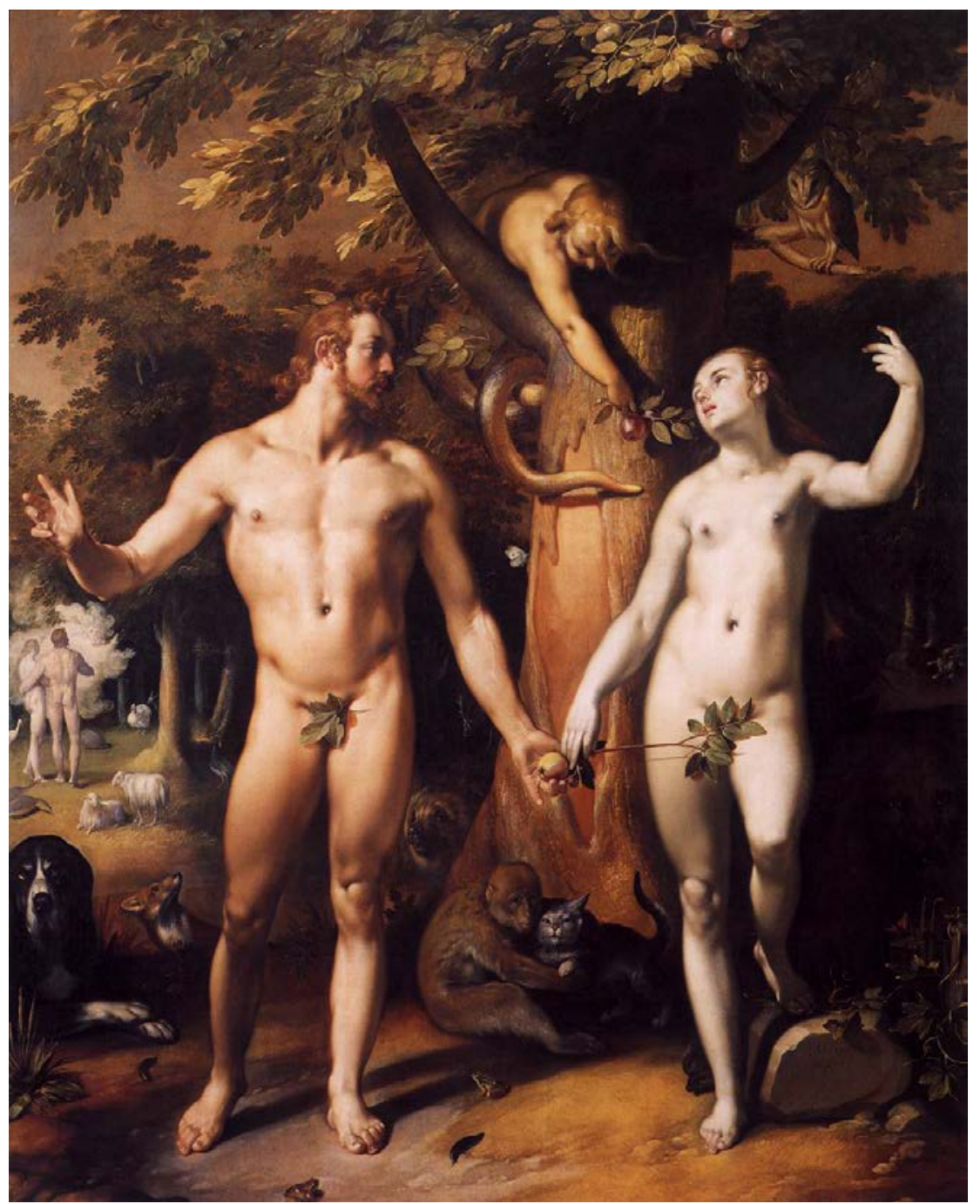

Fig. 9. Cornelis van HaArlem, La caída de los primeros padres, Rijkmuseum, Ámsterdam

El sueño y la muerte, los hijos de la Noche, adormidera y búho, explican el universal pensamiento del artista. Cabría preguntarse cuál es el sentido de la muerte y si queda representado en esa iconografía. La respuesta no se deja esperar y la encontramos bajo el hombro de la Noche, en la máscara, atributo que expresa la inmortalidad del alma, el duende que queda disfrazado y encerrado en el cuerpo como materia [Fig. 10].

Cornelis van Haarlem. La caída de los primeros padres (Rijkmuseum. Ámsterdam).

Salvatore Rosa. Demócrtio en meditación (Statens Museum for Kunts. Copenhague).

Monogramista Mz. Escóndete. Grabado. 


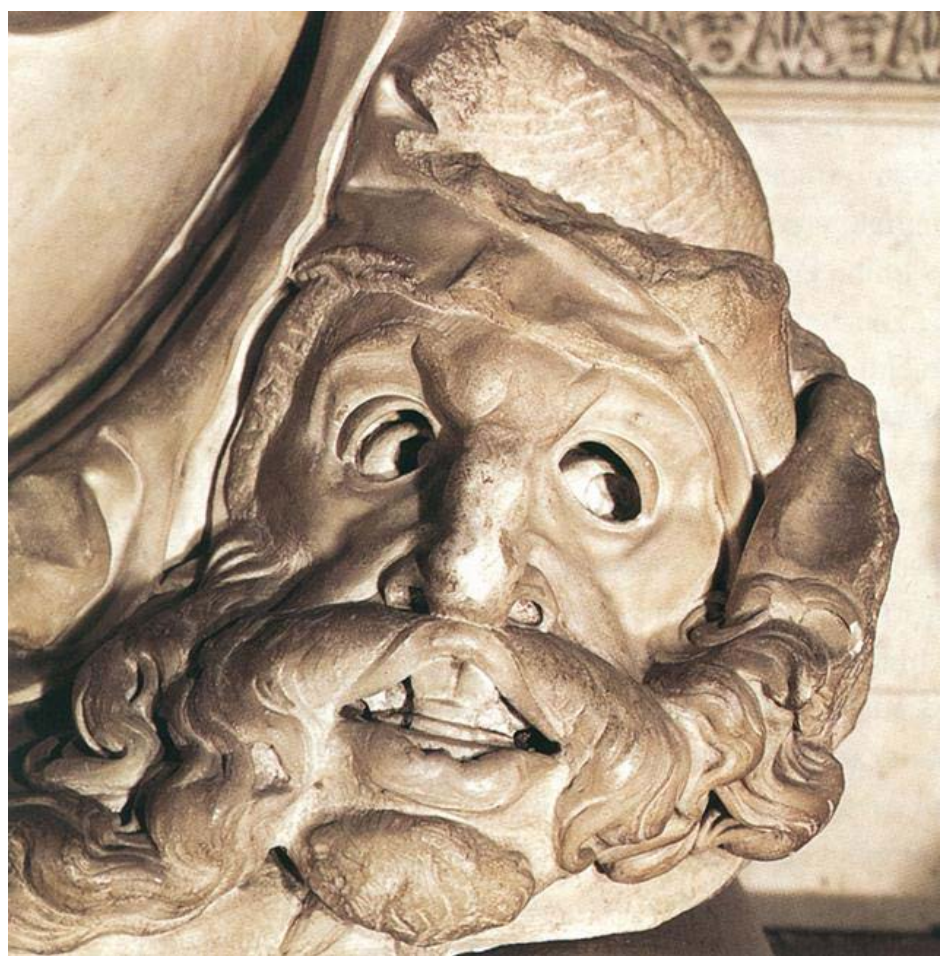

Fig. 10. Michelangelo, Capilla Medicea, La máscara o larva bajo la figura de la Noche

Platón, en el citado Fedón nos habla de la máscara, en latín larva, y lo hace para explicar que el alma, tras la muerte, es inmortal. Lo entiende a modo de «duende», término larva que para Ficino, en la Florencia del siglo xv y en su comentario a Platón lo traducirá por «larvae», es decir, fantasma. Un fantasma que puede atemorizar como a los niños una máscara, pero que no se debe temer por quien ha dedicado su vida al conocimiento. Precisa Platón en su diálogo recogido en el Fedón (77e):

Queda demostrado, pues, lo que decís desde este momento incluso. No obstante, me parece que, tanto tú como Simmias, discutiríais con gusto esta cuestión con mayor detenimiento, y que teméis, como los niños, que sea verdad que el viento disipe el alma y la disuelva con su soplo mientras está saliendo del cuerpo, en especial cuando se muere no en un momento de calma, sino en un gran vendaval.

Cebes, entonces, le dijo sonriendo:

- Como si tuviéramos ese temor, intenta convencernos, oh Sócrates. O mejor dicho, no como si fuéramos nosotros quienes lo tienen, pues tal vez haya en nuestro interior un niño que sea quien sienta tales miedos. Intenta, pues, disuadirle de temer a la muerte como a la máscara (duende, fantasma, larva). 
Sobre este temor, infundado en el hombre que dedica su vida al conocimiento, dice:

Los hombres ignoran que los verdaderos filósofos no trabajan durante su vida sino para prepararse a la muerte; y siendo esto así, sería ridículo que después de haber perseguido sin tregua este único fin, recelasen y temiesen, cuando se les presenta la muerte.

El emblemista Cast, recoge en su cuerpo figurado del emblema y con el mote Mors Larvae similes este aspecto: el temor a la muerte y lo hace siguiendo con claridad el texto señalado en el Fedón, es decir, mediante la máscara, la larva que asusta a los niños y a los ignorantes [Fig. 11] ${ }^{10} \mathrm{El}$ sentido platónico quedó reflejado en recreaciones de sarcófagos romanos en el siglo II donde la larva o máscara, inserta en la cabeza de un niño, se presenta ante un joven que, con sus manos manifiesta asombro y sorpresa, pero lejos de atemorizarse, acepta la muerte con agrado.

Brueghel en su citada pintura el Triunfo de la Muerte, dispone al esqueleto con la máscara, un claro duende o fantasma que atemoriza a los jóvenes en su juego y diversión [Fig. 12]. No extraña, en consecuencia, que Antonio de Pereda, en su Sueño del caballero presente la máscara junto al cráneo con este mismo sentido, atemorizando al caballero como anuncio del final de la vida, pues como reza el mote que acompaña al ángel, la muerte llega rápidamente. ${ }^{11}$ Giacinto Gimignani en el siglo XVII nos ofrece un dibujo recreando a un anciano sentado; la muerte se figura por el esqueleto junto a un niño que porta una máscara, similares elementos a los descritos por el emblemista Cast en referencia a la muerte como duende o fantasma que asusta en su presencia [Fig. 13].
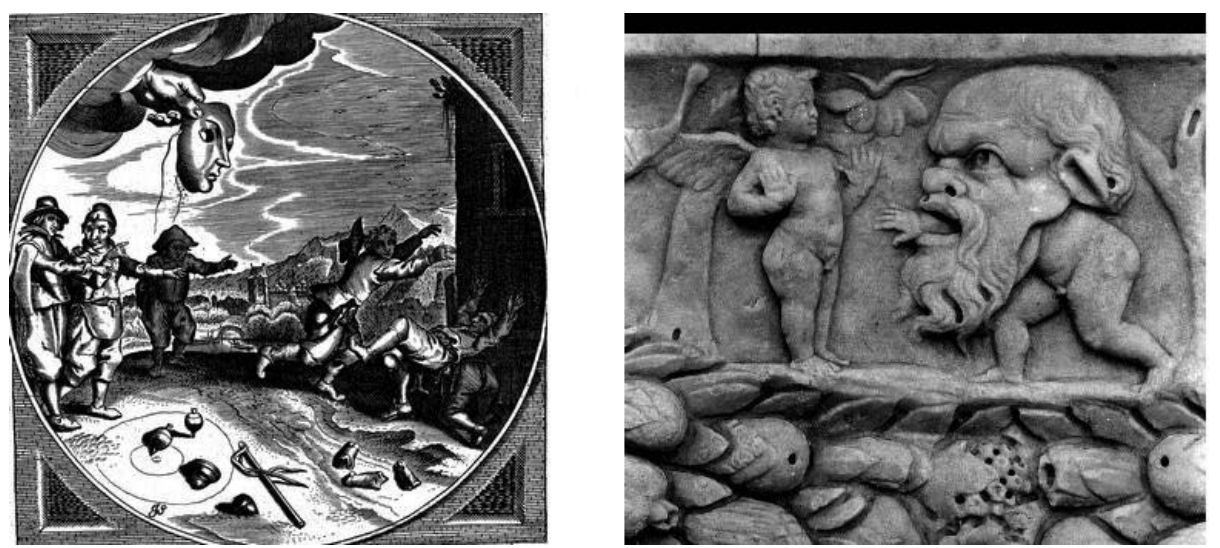

Fig. 11. Јасов CAтs, Proteus. Mors Larvae similes

10. Јасов CATS: Proteus, Ed. 1658. Mors Larvae similes.

11. Antonio de Pereda, Sueño del caballero (Academia de San Fernando). 


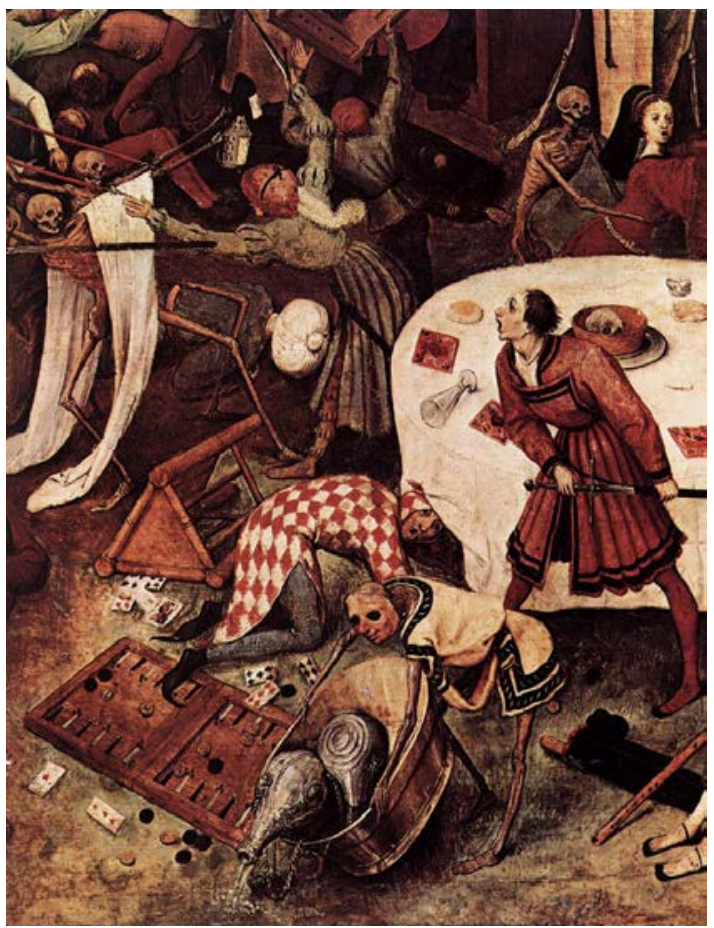

Fig. 12. Brueghel, P., Triunfo de la Muerte, Museo del Prado. Detalle, la muerte con máscara

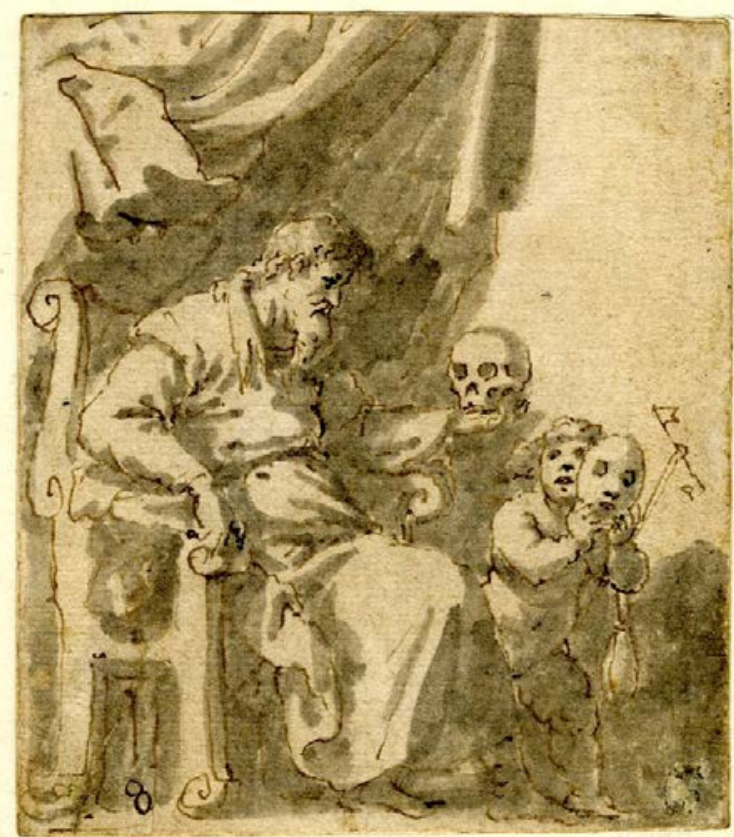

Fig. 13. GimignANI, G., La muerte y la máscara, siglo XVII 
Edgar Wind apunta uno de los jeroglíficos de Horapolo en este sentido donde dos ojos se disponen sobre la máscara. Nos dice que la imagen representa a los dioses Manes, ejemplo de las tinieblas y lo propiamente infernal. En este sentido conviene apuntar que el jeroglífico señalado no se encuentra en la antigua edición de los Hieroglyphica, más bien se corresponde a uno de los añadidos que hiciera Giulio Franceschini en su edición de Roma en 1597 con 184 estampas [Fig. 14].

Cesare Ripa fundamenta una de sus iconografías sobre la muerte mediante la máscara señalando una misma intencionalidad, la máscara como medio, como duende que llega a cada uno de manera distinta, a unos asusta, a otros conforta [Fig. 15]:

Camillo de Ferrara, pintor excelente, representó a la muerte con toda su osamenta, sus músculos y sus nervios, ostensiblemente marcados... En la cabeza puso una delicada máscara de bellísimo color y fisonomía, pues la muerte no se muestra para todos la misma, sino que transformándose continuamente con sus mil caras agrada a unos, disgusta a otros, unos la desean, otros la huyen, siendo el fin de una prisión oscura para los ánimos generosos, mientras para otros es daño y necesidad...

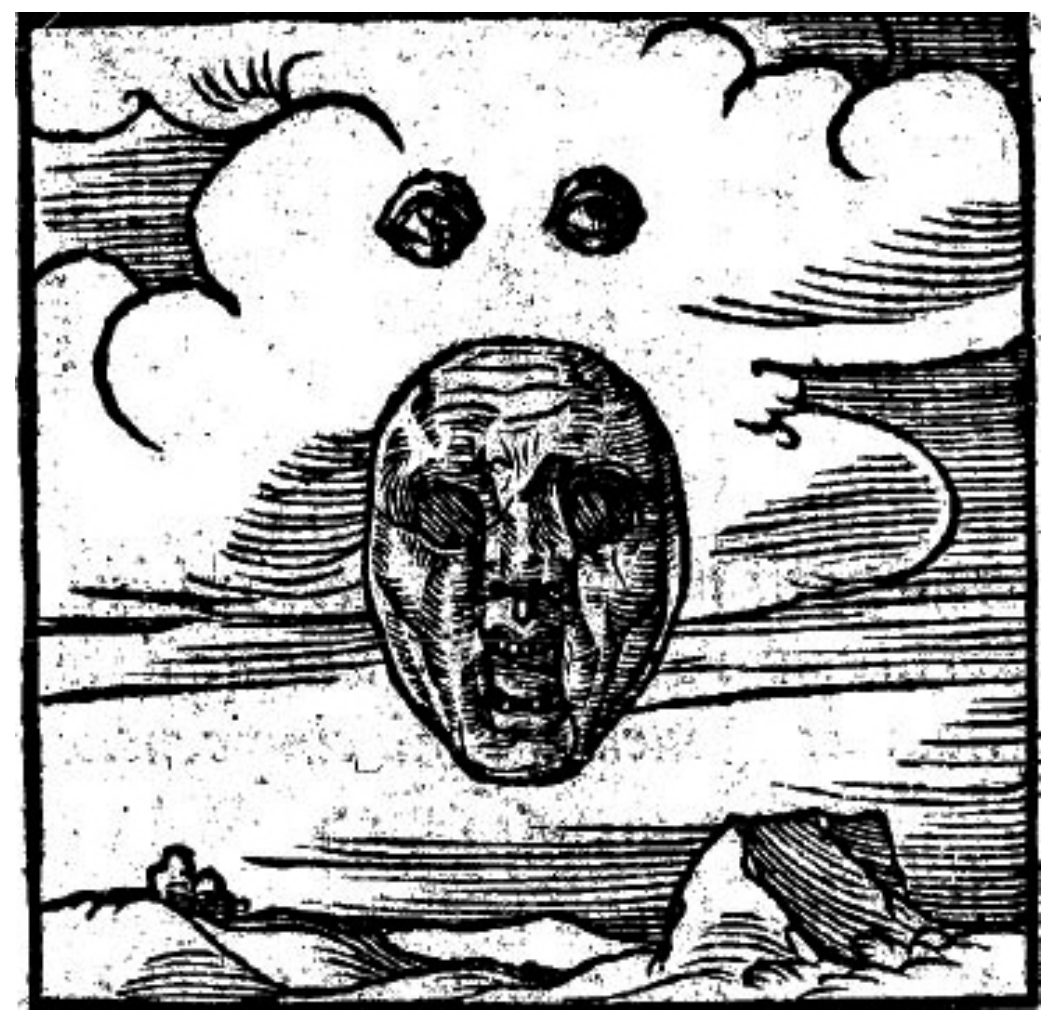

Fig. 14. Hieroglyphica, de Horapolo, Edición Giulio Franceschini, 1597. Máscara 


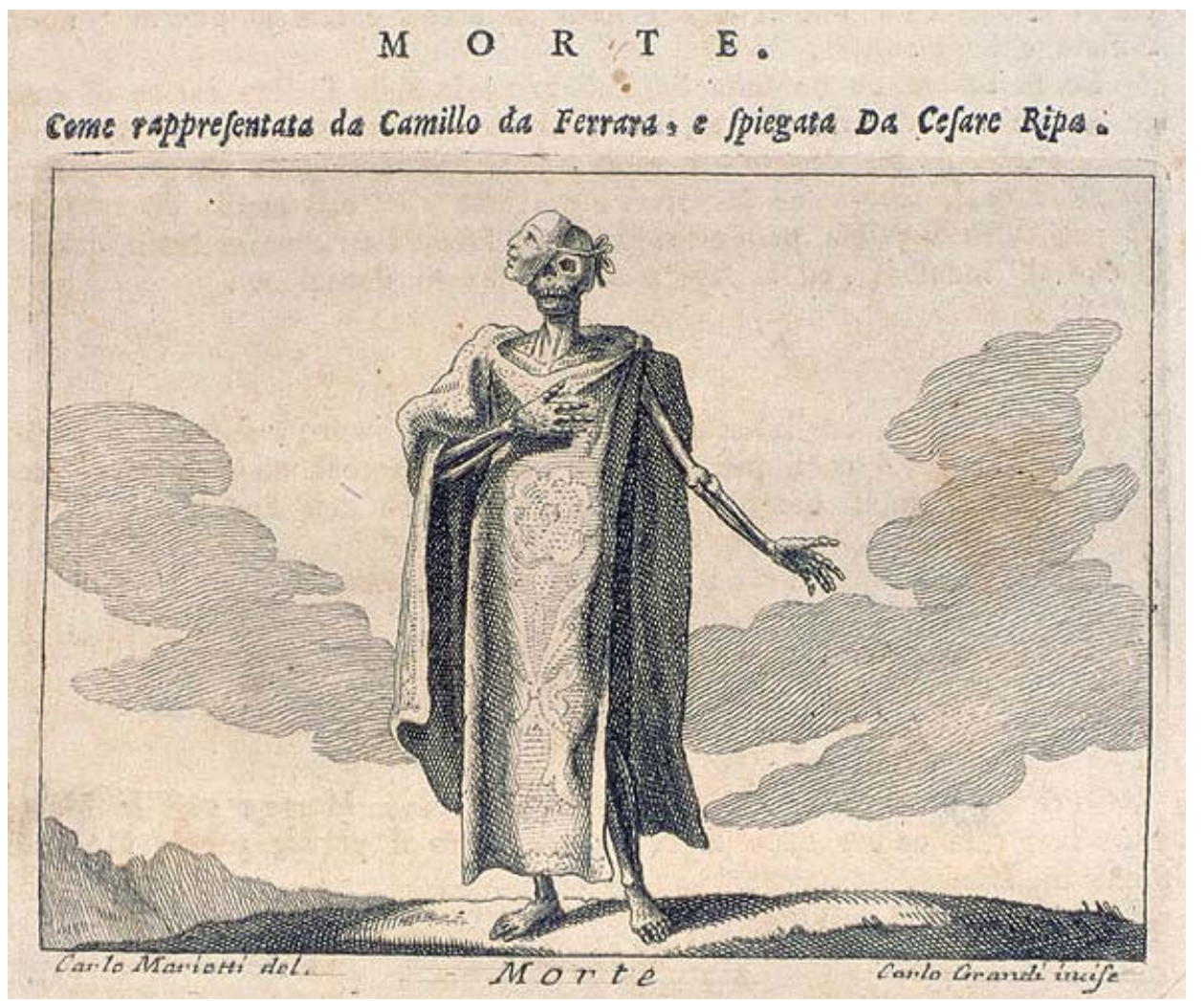

Fig. 15. RiPA, C., Iconologia. Morte

Michelangelo, en su juventud, hacia 1484, comenzó su formación en el taller de Domenico Ghirlandaio (1449-1494). El hijo de Domenico, Ridolfo (14831561), afamado pintor en el Renacimiento, elaboró un óleo sobre madera hacia el año 1510 conservado en la actualidad en la florentina Galería Uffizi. La pintura nos presenta a una joven mujer que lleva un libro en su mano con la inscripción «IHS» por lo que se ha titulado el retrato como Joven monja. Lo curioso es que el retrato incluye otra pintura diseñada para cubrirlo; un falso panel pintado con relieves grotescos que rodea una máscara bajo el mote: Sua Cuique Persona, que se ha traducido como: «A cada uno su máscara». Bien puede entenderse en el sentido que cada persona oculta su verdadera identidad o, quizá, en relación con lo que llevamos dicho, que cada uno tiene su propio duende, sus propios miedos o fantasmas. El mote latino parece provenir de Quintiliano en su Institución Oratoria $(\mathrm{V}, 13)$, aunque también se encuentra en Séneca (De Beneficiis II, 17) [Fig. 16]. ${ }^{12}$

12. Quintiliano: «Illae firmiores es sua cuique persona probationes, quae credibilem rationem subiectam habent: ut vulneratus aut filio orbatus non fuerit alium accusaturus...».

Séneca: «Adspicienda ergo non minus sua cuique persona est quam eius...». 


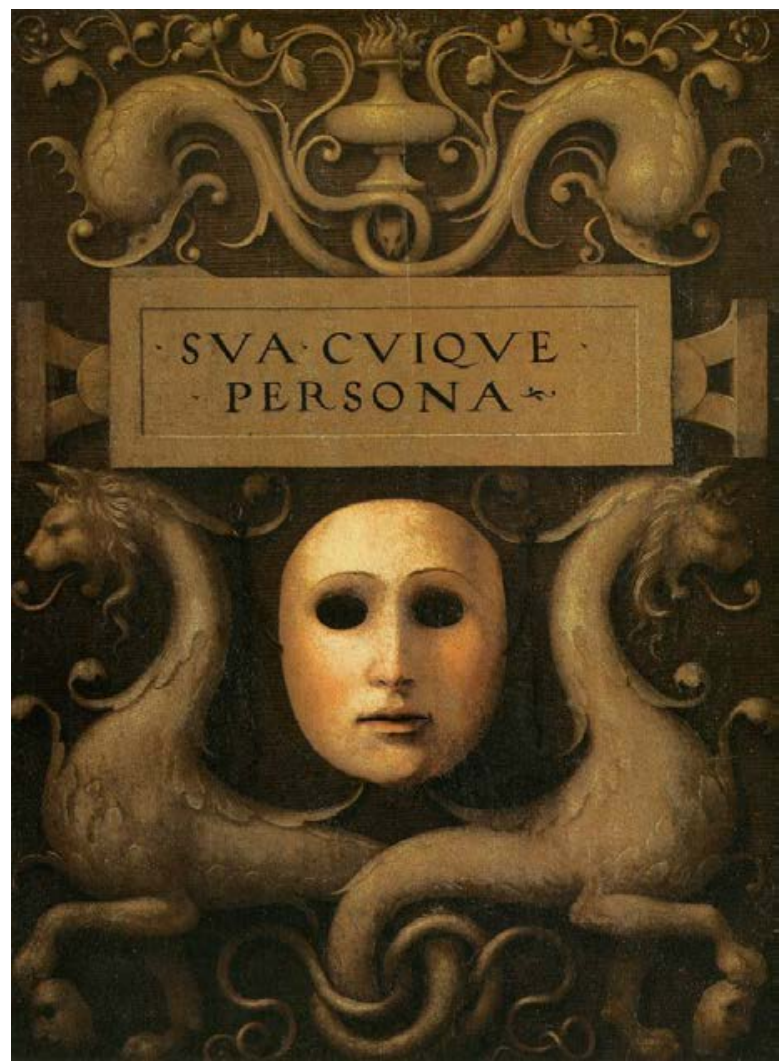

Fig. 16. Ghirlandaio, R., Máscara. Lema: Sua cuique persona. Galería Uffizi. Florencia

Un soneto de Michelangelo nos habla de su visión de la muerte:

Cada vez que mi ídolo se aparece

a los ojos de mi corazón constante y débil,

entre uno y otro ser entra la muerte,

y me aleja cuanto más me espanta (LVII).

No extraña, en consecuencia, que Antonio de Pereda (1611-1678), en su Sueño del caballero de hacia el 1660 y conservado en la Real Academia de San Fernando, recree a un joven en postura melancólica sumido en el sueño; sobre la mesa reposan todos los atributos comunes en la época barroca como imagen de la vanitas, la vela apagada expresa el final de la vida como lo apreciamos en Valdés Leal y en otros artistas como Saint-André. Junto a ellos, dos cráneos y una máscara [Fig. 17]. La composición, postura melancólica, el ángel indicando el final, recuerda la estampa de Michel Coxie I sobre san Jerónimo y su visión del Juicio Final donde el real transido con serpientes en su corona expresa con claridad la misma intención de vanitas que nos ofrece 


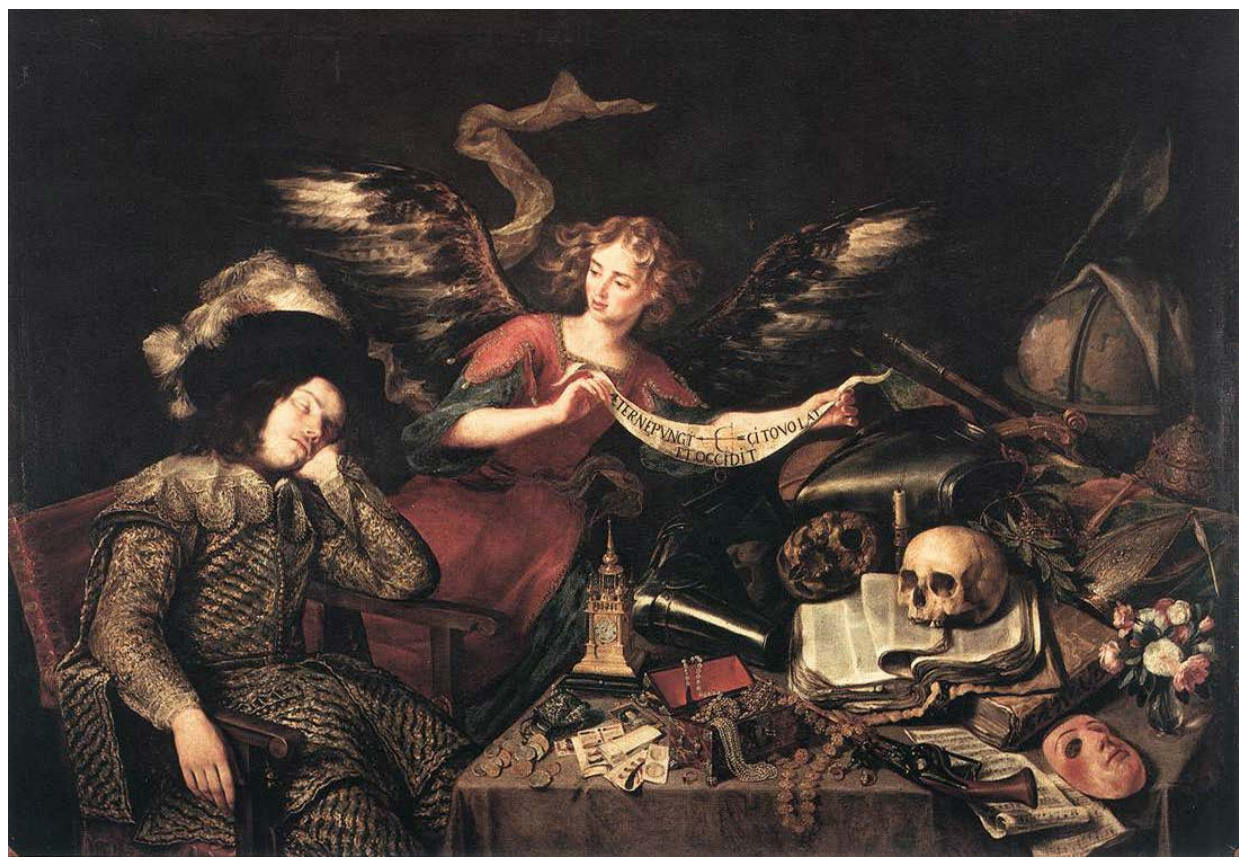

Fig. 17. Pereda, Antonio de, Sueño del caballero, Academia de San Fernando

Pereda, y así se señala en la zona inferior de la lámina: Vanitas Vanitat et omnia Vanitas (Ecl. 1,2) [Fig. 18]. La iconografía está en clara dependencia de la composición de Erhard Schön que realizara en 1532 donde apreciamos las serpientes que rodean la corona de la muerte.

En el lienzo, como hemos señalado, está presente la máscara junto al cráneo como anuncio del final de la vida, pues como reza el mote que acompaña al ángel: la muerte llega rápidamente.

Aeterne pungit, cito volat et occidit.

Eternamente hiere, vuela veloz y mata.

La máscara en esta pintura se ha considerado como referencia al fraude engañoso de las vanidades en la vida, de ahí todas las figuraciones que observamos en la composición; también como atributo de la musa Talía, es decir, como un teatro que supone el discurrir por la vida. No obstante, al disponerse junto a los cráneos bien puede fundamentar el sentido que comentamos y así ha sido muy considerado en el arte, la figuración del duende o fantasma que, a modo de máscara, se aparece en el último sueño que da paso a la noche final, pues como reza el escrito en la filacteria, muy similar en su intención a la pintura de Valdés Leal, in ictu oculi, pues la muerte llega en un abrir y cerrar de ojos. 


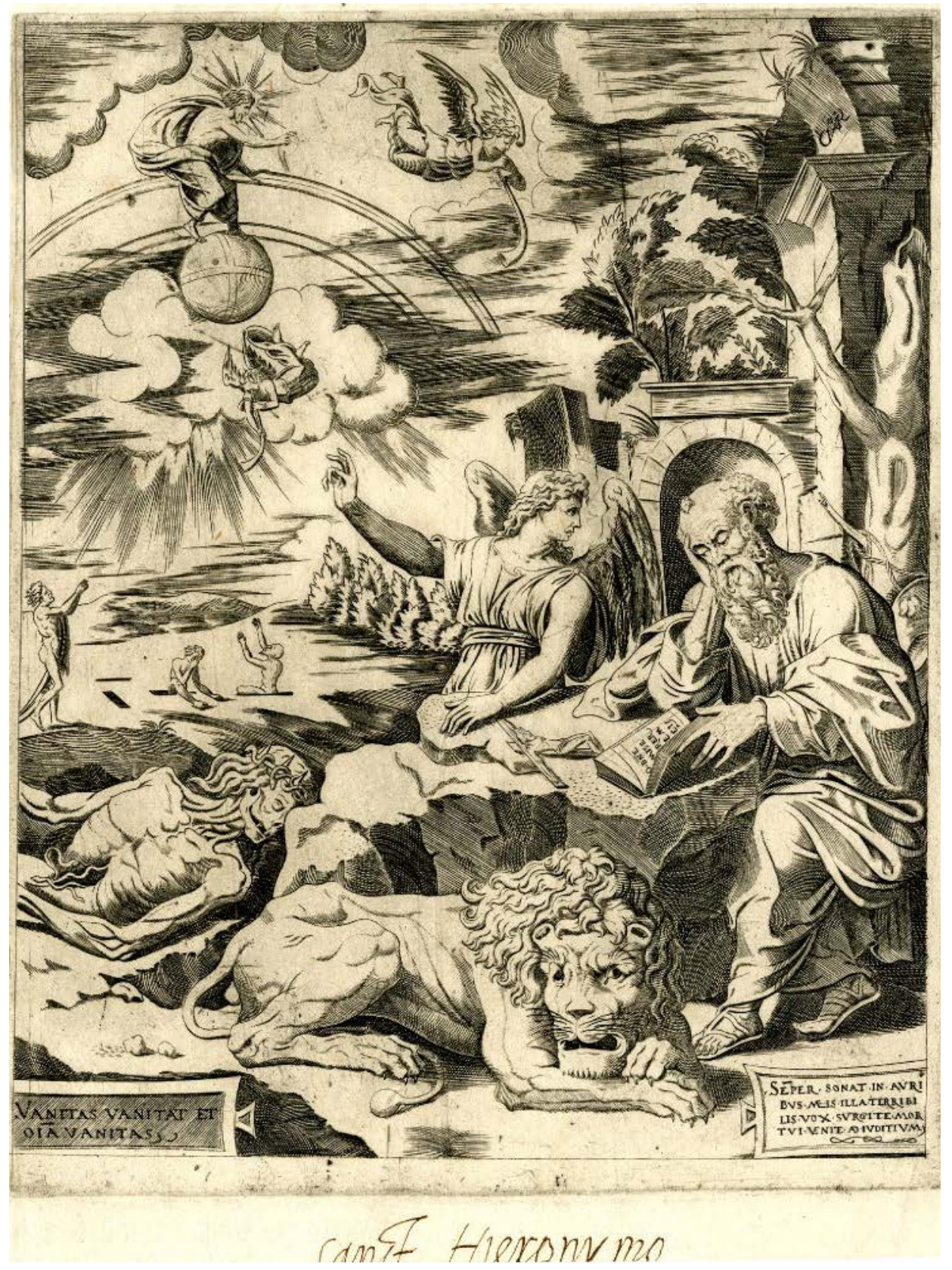

Fig. 18. Michel Coxie I, San Jerónimo y su visión del Juicio Final 
Volviendo a nuestro comentario, vamos dando cuenta de la Noche como expresión del tiempo a través del Sueño, como fin del tiempo terreno mediante el búho, de la llegada imprevista de Thanatos y, finalmente, de una muerte como duende, como máscara que esconde el verdadero valor de la vida, un alma inmortal como también recoge Cicerón. En el citado comentario al Sueño de Escipión, el cuerpo es muerte por vivir en la tierra, pero el alma esta llamada a volar hacia las esferas celestes como explicó Platón. Michelangelo así se expresa en alguno de sus sonetos:

Cierto de la muerte, no aún de la hora, la vida es breve y poco ya me resta; grata a los sentidos, pero no morada del alma, que me ruegas muera.

Es ciego el mundo y aún el triste ejemplo vence y sumerge toda costumbre buena; se apagó la luz y en ella la confianza, triunfa lo falso y la verdad no brota. Ay ¿cuándo vendrá, Señor, lo que aguarda quien en ti cree? Pues la mucha tardanza la fe corta y hace al alma mortal.

¿Qué vale que nos prometas tanta luz, si antes llega la muerte, y sin refugio para siempre nos deja donde nos alcanza? (LXXV).

\section{LA MUERTE COMO METAMORFOSIS Y LIBERACIÓN DE LA PRISIÓN CORPORAL}

Sabemos que el término larva, además de señalar máscara o duende, en italiano viene a referir la metamorfosis sufrida por ciertos animales en una juventud o primer estado, pues adquieren esta configuración en espera de una transformación y desarrollo posterior. Las larvas comen el cadáver, son sarcófagos en movimiento como los referidos en mármol, pues el término viene a significar «el que devora la carne» y devora la materialidad para transformarse, como diría Santa Teresa, de afeado gusano en bella mariposa, insecto que en el discurso iconográfico ha venido a expresar lo más espiritual del hombre, su alma. En consecuencia, toda una nueva resurrección. ${ }^{13}$ Así lo recoge Michelangelo en sus sonetos:

Veo en tu hermoso rostro, mi señor, algo que mal se encuentra en esta vida: el alma de la carne aún vestida (xxix).

13. GonzÁlez de Zárate, J. M.: Mitología e Historia del Arte, Prometeo.

Así lo apreciamos en un sarcófago romano de Prometeo en el siglo III, donde el artífice crea lo material del hombre con barro, su mero cuerpo, pero es Atenea quien le infunde su valor espiritual que queda representado por la mariposa como elemento ingrávido, volátil y espiritual, es decir, como imagen del alma. 
El encendido amor, que desenlaza el alma,

calamita le es a un similar ardor,

y como oro purgada en fuego, retorna a Dios (LVII).

Y este es el propósito final de Michelangelo, expresar que la llegada imprevista de la muerte no supone un final, es tan solo una metamorfosis, una transformación donde perece lo corporal a modo de gusano para trascender a lo espiritual y eterno. Toda una liberación de la prisión corporal que, por los engañosos sentidos, retiene su vuelo a la inmortalidad. Así lo considera Platón, el cuerpo como cárcel, en el citado diálogo que seguimos (83a).

Engelgrave en su Lux Evangelica sub velum Sacrorum Emblematum recondita... se explica con similar imagen, concretamente en su Emblema XxI dedicado al domingo de Resurrección donde, el gusano queda transformado en mariposa. En su mote, siguiendo el evangelio de san Marcos, señala: surrexit, non est hic (Resucitó y no está aquí), al igual que el alma, pues a modo de duende ya no residirá en lo terreno abandonando el sarcófago en su carne ya devorada por unas larvas que la han transformado en puro espíritu [Fig. 19]. ${ }^{14}$

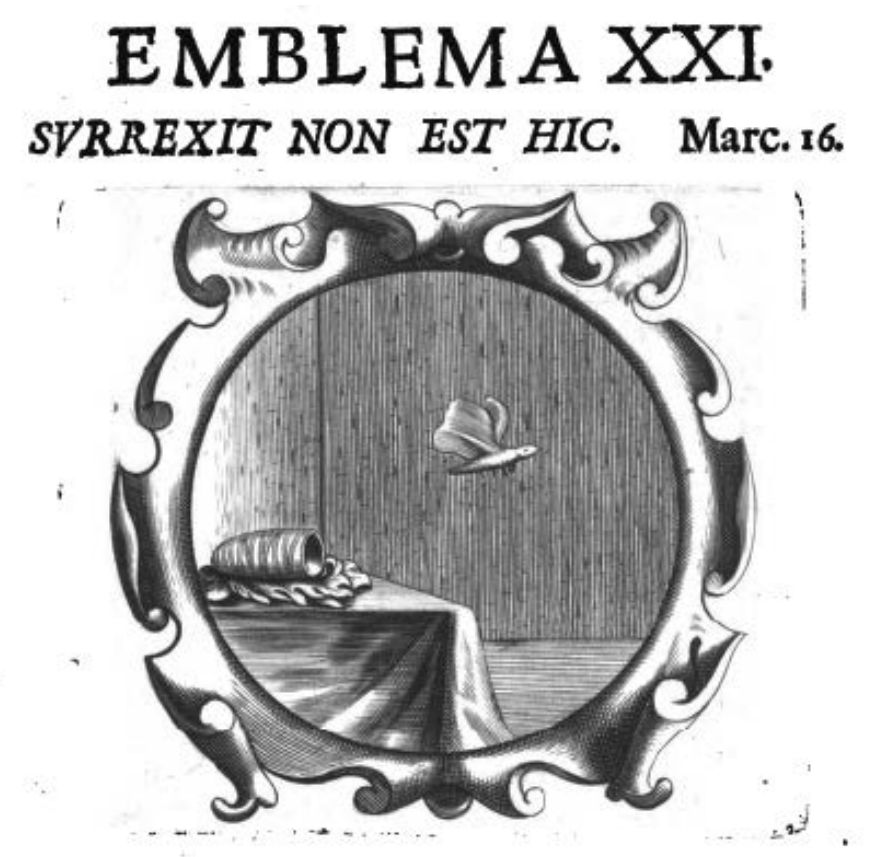

ALBVM MVTOR IN ALITEM. Horat. DOMINICA RESVRRECTIONIS.

Fig. 19. ENGElgrave, Lux Evangelic asub velum Sacrorum Emblematum recondita... Emblema XXI

14. Engelgrave: Lux Evangelic asub velum Sacrorum Emblematum recondita..., Amberes, 1552. 
Los místicos en la edad del Humanismo nos proponen similares ejemplos a los representados. Santa Teresa de Jesús en sus Moradas o Castillo interior (Morada V, cap. II), nos ofrece estas lecturas y al hablar del gusano nos dice:

... con hojas de moral se crían, hasta que, después de grandes, les ponen unas ramillas y allí con las boquillas van de sí mismos hilando la seda y hacen unos capuchillos muy apretados adonde se encierran; y acaba este gusano que es grande y feo, y sale del mismo capucho una mariposica blanca, muy graciosa. ... ¡Muera, muera este gusano, como lo hace en acabando de hacer para lo que fue criado!, y veréis cómo vemos a Dios y nos vemos tan metidas en su grandeza como lo está este gusanillo en este capullo. Pues veamos qué se hace este gusano, que es para lo que he dicho todo lo demás, que cuando está en esta oración bien muerto está al mundo: sale una mariposita blanca.

... ¡Oh grandeza de Dios, y cuál sale una alma de aquí, de haber estado un poquito metida en la grandeza de Dios y tan junta con El; que a mi parecer nunca llega a media hora! Yo os digo de verdad que la misma alma no se conoce a sí; porque, mirad la diferencia que hay de un gusano feo a una mariposica blanca, que la misma hay acá. Ya no tiene en nada las obras que hacía siendo gusano, que era poco a poco tejer el capucho; hanle nacido alas, ¿ cómo se ha de contentar, pudiendo volar, de andar paso a paso? Todo se le hace poco cuanto puede hacer por Dios, según son sus deseos.

... Parece que me alargo, y mucho más podría decir, y a quien Dios hubiere hecho esta merced verá que quedo corta; y así no hay que espantar que esta mariposilla busque asiento de nuevo, así como se halla nueva de las cosas de la tierra.

Juan de Rojas así lo recoge en sus emblemas donde podemos leer como interpretación de los escritos de Teresa de Jesús en su décima representación sobre las quintas moradas: ${ }^{15}$

El topo muere en la tierra

Porque en ella está su anhelo;

$\mathrm{Y}$ alas viste para el cielo

Gusano, que en sí se encierra.

El citado Corpus Hermeticum, tan de moda en los tiempos de Michelangelo, insiste con clara huella neoplatónica, en el carácter inmortal del alma abandonando las miserias del cuerpo y así, pone en boca de la Inteligencia Universal, de «Poimandres»:

15. JUAN DE RoJAS: Representaciones de la verdad vestida, misticas, morales, y alegoricas, sobre las siete Moradas de Santa Teresa de Iesus, Gloria del Carmelo, y Maestra de la Primitiva Observancia. Careadas con la noche obscura del B.P.S. Iuan de la Cruz, primer Carmelita Descalço, manifestando la consonancia, que estas dos celestiales plumas guardaron al enseñar a las almas el camino del Cielo. Ilustradas con versos sacros, varios geroglificos, Emblemas, y Empresas, estampadas para mayor inteligencia de la Doctrina de la Serafica Doctora, Madrid, Antonio Gonçalez de Reyes, de 1679. A costa de Gabriel de León, Mercader de Libros. 
Los que habiéndome oído vinieron a mí, y les dije:- ¿Qué pasa con vosotros, oh hombres nacidos de la tierra! ¡Os habéis entregado a la muerte cuando se os ha concedido el poder de la inmortalidad? ¡Reflexionad, vosotros, que hacéis camino con el error y habéis llegado a convivir con la ignorancia! ¡Alejaos de la luz tenebrosa, y abandonando la ruina, compartid la inmortalidad! («Poimandres», 28)

Y enseguida el Dios dijo una palabra santa: «Creced en crecimiento y multiplicaos en muchedumbres, vosotras las criaturas todas y las cosas que han sido hechas, y que el que tiene intelecto se reconozca inmortal y sepa que la causa de la muerte es el amor y que conozca todas las cosas. («Poimandres», 18) ... pero el que se aficionó al cuerpo producto de un extravío de amor quedó extraviado en la tiniebla padeciendo en los sentidos las cosas de la muerte». («Poimandres», 19)

Variados, en consecuencia, son los sentidos semánticos que aporta una misma imagen, de ahí el valor y el estudio en su correcta aplicación a la obra de arte recurriendo a las fuentes literarias que la conforman como soporte de lectura. La Máscara ha recorrido un breve camino, desde la representación como alegoría de la pintura que estudiamos en otro comentario, a la socorrida imagen de lo mundano y engañoso. ${ }^{16}$ También, como acabamos de analizar, al concepto de larva, de duende o fantasma que a cada uno se le presenta en la muerte y que, como metamorfosis, procura la llamada resurrección del alma, la esperanza inmortal que ponga fin a las tinieblas:

Finalmente, reparamos en que la figura de la Noche dispone de dos elementos iconográficos muy singulares sobre su cabeza: la Luna y una estrella de ocho puntas [Fig. 20]. La estrella quizá remita al octavo día de la semana considerado de manera tradicional como la Resurrección de Cristo. También puede estar en relación con las ocho esferas descritas por Cicerón y que son consideradas en el Corpus Hermeticum. Leemos sobre el particular:

Por consiguiente el mundo inteligible depende de Dios, el mundo sensible del inteligible: el Sol suministra al mundo inteligible y al mundo sensible el influjo del bien que recibe de Dios, es decir la actividad creadora.

Alrededor del Sol gravitan las ocho esferas que de él dependen: una la de las estrellas fijas, siete de las errantes, y de éstas una gira en torno de la Tierra. Estas son las esferas de que dependen los genios, y de los genios los hombres. Y así todos y todas las cosas dependen de Dios. (XVI. 17)

Todo depende de Dios, inteligencia a la cual el hombre está llamado en espíritu tras la llegada del duende, de la máscara, de la larva. Y como mediadora entre lo humano y lo divino, la Luna con similar sentido al que nos ofrece María, es decir, como corredentora. Por tanto, la Luna queda recreada sobre una Noche que, por ef ímera, es profundamente humana:

16. GonzÁlez de ZÁrate, J. M.: «De algunas pinturas en el Museo del Prado. Mitos en Metáforas». En Los Dioses Cautivos, Museo del Prado, Madrid, 2011. 


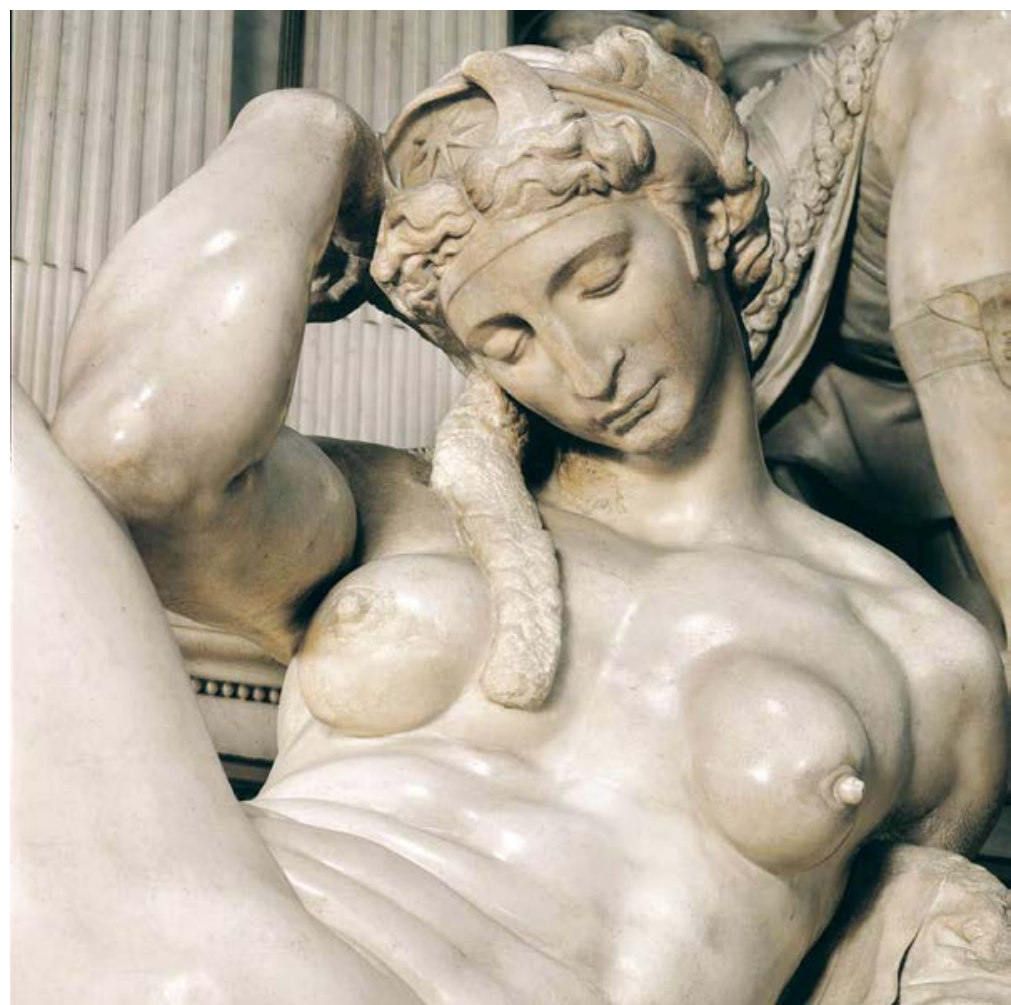

Fig. 20. Michelangelo, Capilla Medicea, La luna y la estrella de ocho puntas dispuestas en la cabeza de la Noche

Mira la Luna, precursora de todos, órgano de la Naturaleza, transformadora de la materia aquí abajo. Mira la Tierra en el medio del Todo, colocada como cimiento del bello mundo, nutricia y nodriza de todos los seres terrestres.

Contempla también cuán inmensa es la multitud de los vivientes inmortales y de los mortales, y, mediadora entre ellos, inmortales y mortales, la Luna rondando su ronda! (XI. 5)

\section{De LA ELEVACIÓN DEL ALMA, LA ANÁbASIS DEL ESPÍRITU}

Cicerón, en el citado Sueño de Escipión, nos habla de los planetas, de las siete esferas que en perfección establecen su órbita alrededor de la naturaleza ogdoádica que son las estrellas fijas de la octava esfera, sin olvidar el noveno círculo, la suprema Inteligencia celeste. Dante, personalidad inserta en el pensamiento miguelangelesco, sin duda tomó esta información y dispone similar distribución considerando por los siete planetas grados de perfección espiritual por los que el alma asciende a la divinidad, realiza su anábasis, 
expresada en este conjunto funerario mediante el domo o cúpula, círculo y esfera perfecta que remite a la idea de Dios. La Noche, en el medio humano, expresa lo terreno, por ello, Michelangelo dispone en su frente la media luna y la estrella de ocho puntas, la primera esfera y las estrellas fijas, es decir, toda la composición planetaria del universo resumida por estos dos elementos.

Y así, el cuerpo queda olvidado en su materialidad terrena, yacente en la tumba. Es el alma, tras la liberación en el Hades, la que asciende a una perfección superior que añoraba presa en la materia. Por tanto, la sentencia de san Jerónimo queda manifiesta y por ello, la muerte no es un final, Thanatos queda vencido ante el nuevo y eterno despertar. De ahí que la denominación tradicional en la cultura cristiana toma el término griego koimeterion, cementerio, dormitorio, lugar del sueño.

Nos dice Jerónimo, considerado en este tiempo como «príncipe del Humanismo»: «Para los cristianos, la muerte no es muerte, es una dormición y por ello se llama sueño» (Epist. XXIX).

En este proceso de elevación, tanto Giuliano, duque de Nemours, como Lorenzo, duque de Urbino, ambos sedentes, miran la figura de la Madonna con el Niño, una Madonna que, en su mirada, ignora al infante redentor y esto es una constante en sus composiciones escultóricas, no así en sus Piedades donde la mirada maternal ante el Hijo muerto es toda una clara poesía en expresión de la piedad.

La mirada de ambos duques a María queda explicada en su dimensión como corredentora en la tradición escultórica funeraria. La fuente la encontramos en Vorágine quien, al hablar de la Asunción a los cielos, pone en boca de Cristo:

Ven ya a reunirte con quien nació de ti; ven a recibir el premio que alcanzaste concibiéndome en tus entrañas; ven a recoger la recompensa de los méritos que acumulaste pariendo, amamantando y criando a tu Unigénito; date prisa y ven cuanto antes a reunirte para siempre con tu Hijo. Todo lo tengo previsto y bien dispuesto para que vengas sin que te produzca angustia la idea de que vas a dejar huérfanos a esos otros hijos tuyos de la tierra tan maternalmente amados por tu corazón, porque cuando te hice mía; ven conmigo a compartir mi trono, porque me tienes cautivado con tu hermosura.

En el citado Corpus Hermeticum, Hermes enseña que el hombre tiene doble naturaleza, mortal e inmortal:

Por esta razón, entre todos los seres que viven sobre la tierra el hombre es mortal en cuanto al cuerpo e inmortal en cuanto al Hombre Esencial. («Poimandres», 15)

Añade:

Primero, me dijo Poimandres, al descomponerse el cuerpo material lo entregas a la transformación, y tu figura humana deja de manifestarse. («Poimandres», 24) 
Este es el sentido final de la señalada máscara, operar como larva en su metamorfosis de gusano que de arrastrarse pasa al vuelo ingrávido de la mariposa. Así, como se ha dicho, se manifesta una transformación de lo material a lo espiritual, un olvido del cuerpo para que pueda dar vida plena al alma:

En cuanto a la transformación, la llaman muerte porque el cuerpo se destruye, mientras que la vida se retira a lo no manifestado. (XI, 15)

Ficino da cuenta de la estructura del cosmos, estructura que Tolnay quiere ver en su estudio sobre Michelangelo a través de las diferentes zonas que conforman los sepulcros mediceos y que Santiago Sebastián recoge en su Arte y Humanismo. ${ }^{17}$ Nos dice el pensador florentino que tras el Mundo Material donde quedarían representados los ríos del Averno, se manifiesta la Región Natural, espacio de los sarcófagos donde, como hemos analizado, transcurren los sucesos humanos hasta la muerte, es el llamado Triunfo de la Muerte. Le sigue el Alma cósmica, esferas planetarias en las que opera la elevación del alma, la anábasis, los estadios de perfección del espíritu. ${ }^{18}$ En el Corpus Hermeticum podemos leer:

Y así, de ahora en más, el hombre comienza a subir por la estructura: en la primera esfera deja la energía de aumentar y decrecer; en la segunda la industriosidad para el mal, dolo ya inactivo; en la tercera, el deseo, fraude ya inactivo; en la cuarta la ostentación del mando, ya sin ambición; en la quinta la osadía profana y la presuntuosa temeridad; en la sexta las ansias perversas de la riqueza, ya sin actividad; y en la séptima esfera la tramposa mentira. («Poimandres», 25)

Finalmente y como coronamiento de los sepulcros se manifiesta, mediante la cúpula, el domo, la Mente Cósmica o Inteligencia divina. Nos dice:

Entonces, desnudo de las obras de la estructura, entra en la naturaleza ogdoádica, dueño de su propia fuerza, y canta himnos con los seres al Padre. Entonces todos los que presencian su llegada se regocijan con él, y, ya igual a sus compañeros, alcanza a oír a las potencias superiores a la naturaleza ogdoádica que con voz dulce y peregrina cantan himnos al Dios. («Poimandres», 26) (Ogdoádica, la octava esfera señalada por Cicerón)

Mente, Alma, Región Natural y Mundo Material son conceptos explicados en la cosmogonía de Ficino que quedaron recogidos en el Corpus Hermeticum como referencia a la explicación del mundo:

Préstame ahora toda tu atención, cuanto pueda tu mente, cuanto valga tu astucia. Porque la razón de lo divino, que se conoce por aplicación de la

17. Tolnay, Miguel Ángel escultor, pp. 39-40.

18. Sebastián, Arte y Humanismo, Madrid, 1978, p. 297. 
mente divina, es semejante a un torrente que se precipita de lo alto con impetuosidad incontenible, de manera que, por la gran rapidez, se adelanta a nuestra percepción, no sólo de los que la están escuchando sino también de los que la enseñamos. Prosigamos. El Cielo, dios sensible, es quien administra todos los cuerpos, cuyo crecimiento y disminución dependen del Sol y de la Luna. Pero el Cielo, y la misma Alma y todas las cosas, Dios que las creó es el que las gobierna. Desde todos estos cuerpos celestes, gobernados por Dios mismo, emanan constantes influencias que se ejercen a través de la materia y del ser íntimo de todas las especies y de cada individuo en la general naturaleza. La materia ha sido preparada por Dios para ser el receptáculo de las formas múltiples individuales, pero la Naturaleza conforma la materia en lo particular por medio de los cuatro elementos y conduce hasta el Cielo la totalidad de los seres que complacen las miradas de Dios. (II, 3)

\section{A MODO DE CONCLUSIÓN}

Si bien Alberti en su tratado De pittura puntualizaba que lo más importante en las artes son los asuntos, las historias que se presentan, ha sido nuestro interés discurrir no solamente por los asuntos, también por la propia Historia que la imagen contiene, es decir, en sus precedentes tanto visuales como literarios. En consecuencia, «historiar la forma». En este aspecto se centra la Iconografía que es lo mismo que decir la Historia del Arte pues, como Historia, no deja de ser y explicar el tiempo, por tanto y esencialmente por esta disciplina entendemos el discurso del Arte, el discurrir de la Imagen, a modo de documento, en el tiempo. Así, tratar de sus precedentes establece lo que específicamente entendemos por la Historia del Arte, ciencia que se aleja de otros planteamientos formales objetivamente tratados por aquellos especialistas conocedores de técnicas, tratamientos y comportamientos de las Bellas Artes ya catalogadas por Charles Batteux desde el siglo XviII.

$\mathrm{Y}$ es que surge la pregunta: ¿quién repara en los contenidos o asuntos?, de igual manera: ¿quién se ocupa de imagen como concepto semántico? La respuesta la podemos encontrar en la metodología iconográfica, en el describir el objeto, identificar la forma y clasificarla en su origen, en el espacio y en el tiempo. Revivir, en consecuencia, el viejo dicho: ut pictura poesis. Para ello imagen y palabra han de caminar en una misma dirección al entender por aquella un discurso que se conforma en una época con un claro sentido significante que hoy, parece olvidado al ignorar las fuentes que lo generaron. La pintura de Claiessens así lo explica, en ella el arte de la pintura se acompaña de las tradicionales liberales porque la imagen en figura resume toda una profunda intencionalidad parlante dirigida al hombre y que supera el ejercicio en la búsqueda de lo exclusivamente bello.

Este ha sido el único propósito de nuestro acercamiento a la tumba medicea de Giuliano en la que Michelangelo no nos habla de un solo hombre, por muy duque que fuera, ignora las tradicionales virtudes que acompañan 
al yacente en el llamado arte funerario, se trata de una concepción universal de la muerte y resurrección. Es, en consecuencia, el resultado visual de un pensador y hacedor como lo fue el genio florentino, el resumen cristiano del concepto de la vida, muerte y resurrección para todo ser nacido. Apoyado en el pensamiento platónico, en la influencia de Ficino y en el afamado, para la época, Corpus Hermeticum, el artista, de manera sumaria pero profunda, busca en su imaginario las respuestas y... las encuentra. Así, la escultura del duque que preside el conjunto funerario poco tiene que ver con su particular fisonomía, pues en el bulto marmóreo quedan todos figurados [Fig. 21].

La Noche y sus hijos, Hipnos y Thanatos, es decir, la oscuridad transitoria en el día a día por el sueño y la final carencia de luz con la muerte, son figuradas por la adormidera y el búho, ave de la muerte imprevista. La larva, como máscara, expresa una doble intencionalidad. Es el duende de Platón, el fantasma de Ficino, que remite a su llegada y diferente presentación en cada hombre como lo recoge la emblemática. Por otra parte, expresa el estado de descomposición, el gusano que sufre la metamorfosis y de lo terreno surge el vuelo, de lo corporal abandonado en el medio terrestre llega la anábasis o elevación a la perfección infinita y eterna.
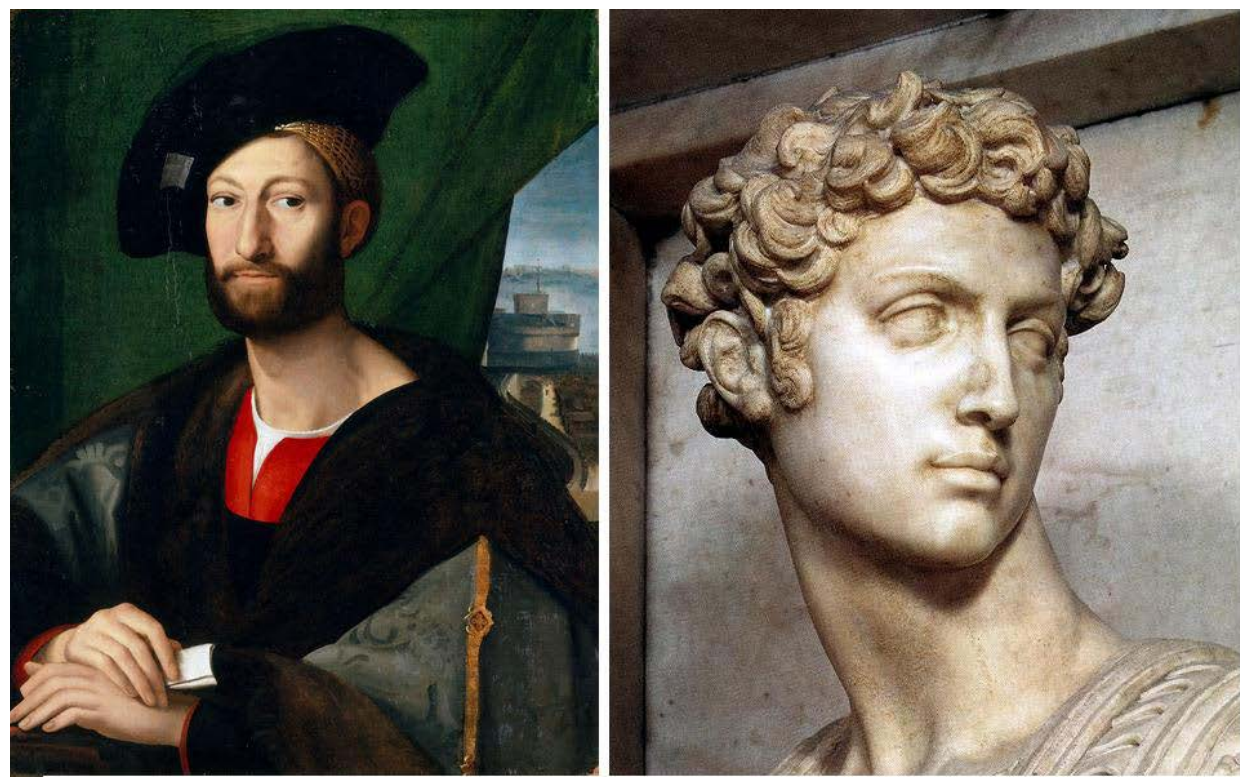

Fig. 21. Rafael, Retrato de Giuliano, duque de Nemours, Metropolitan Museum of Art. MiChelangelo, figuración escultórica de Giuliano 